\title{
Short-term changes in plasma and milk fatty acid profiles in cows fed chopped elephant grass-based diets containing two types of sunflower oil associated with two methods of concentrate feeding
}

\section{Mudanças de curto prazo no perfil de ácidos graxos do plasma e leite de vacas alimentadas com dietas à base de capim-elefante picado, dois tipos de óleo de girassol e dois modos de fornecimento do concentrado}

Fernando César Ferraz Lopes ${ }^{1 *}$; Carlos Gustavo Santos Ribeiro2; Norberto Mario Rodriguez ${ }^{3}$; Marco Antônio Sundfeld da Gama4; Mirton José Frota Morenz ${ }^{4}$

Highlights

21 days was sufficient to understand the main changes in plasma and milk FA profiles.

Cows fed a concentrate supplied twice a day showed a healthier milk FA profile.

Medium oleic sunflower oil-fed cows produced milk with $81 \%$ higher rumenic acid level.

High oleic sunflower oil-fed cows produced milk with $14 \%$ higher oleic acid level.

\begin{abstract}
This study was carried out in a randomized block design in a $2 \times 2$ factorial arrangement with the aim of evaluating the short-term changes in the plasma and milk fatty acid (FA) profiles of Holstein $x$ Gyr cows ( $444 \pm 84 \mathrm{~kg} ; 75 \pm 31$ days in milk; $15.4 \pm 4.8 \mathrm{~kg}$ day ${ }^{-1}$ of milk) fed $600 \mathrm{~g} \mathrm{~kg}^{-1} \mathrm{DM}$ chopped elephant grass-based diets supplemented with $45 \mathrm{~g} \mathrm{~kg}^{-1} \mathrm{DM}$ sunflower oil (SO) for 21 days. Two types of SO were evaluated: high oleic/low linoleic acid ( $\mathrm{HO}$ ) and medium oleic/medium linoleic acid (MO). The concentrates containing SO were supplied separately from forage twice a day (TAD) or as part of a total mixed ration (TMR). Temporal changes were analyzed by mixed models $(P<0.05)$ using six, four and seven repeated measures over time for FA intake and the plasma and milk FA compositions, respectively. There was higher oleic acid intake in

1 Analyst, Dr., Brazilian Agricultural Research Corporation, EMBRAPA Dairy Cattle, Juiz de Fora, MG, Brazil. E-mail: fernando.lopes@embrapa.br

2 Prof., Basic, Technical and Technological Education, EBTT, Dr., Federal Institute of Education, Science and Technology, IFB, Campus Planaltina, Brasília, DF, Brazil. E-mail: carlos.ribeiro@ifb.edu.br

${ }^{3}$ Prof. Emeritus, PhD., Department of Animal Science, Veterinary School, Federal University of Minas Gerais, UFMG, Belo Horizonte, MG, Brazil. E-mail: norberto.bhe@terra.com.br

${ }^{4}$ Researchers, Drs., EMBRAPA Dairy Cattle, Juiz de Fora, MG, Brazil. E-mail: marco.gama@embrapa.br; mirton.morenz@ embrapa.br

* Author for correspondence
\end{abstract}

Received: Sept. 17, 2020 - Approved: Dec. 17, 2020 
HO SO-fed cows, while higher linoleic and $\alpha$-linolenic acid intake were observed in MO SO-fed cows. TADfed cows had a higher plasma vaccenic acid content than TMR-fed cows, while MO SO-fed cows had higher plasma vaccenic and rumenic acid contents than $\mathrm{HO} S \mathrm{SO}-\mathrm{fed} \mathrm{cows.} \mathrm{As} \mathrm{a} \mathrm{function} \mathrm{of} \mathrm{day,} \mathrm{there} \mathrm{were} \mathrm{linear}$ increases in oleic and linoleic acid intake; plasma contents of oleic, vaccenic and linoleic acids; and the milk fat content of linoleic acid, while quadratic effects were adjusted for the milk fat contents of palmitic, oleic, vaccenic and rumenic acids. In comparison with TMR-fed cows, the milk fat of TAD-fed cows produced between days 13 and 17 showed an FA profile that was more nutritionally desirable for human health, with lower contents of hypercholesterolemic FAs and higher contents of oleic, rumenic and vaccenic acids. Between days 15 and 16, the vaccenic and rumenic acid contents in the milk fat of MO SO-fed cows were $81 \%$ higher than those obtained from HO SO-fed cows, which on the $14^{\text {th }}$ day had a $14 \%$ higher oleic acid content in milk fat. Lower milk fat levels of hypercholesterolemic FAs were produced between days 13 and 14 by cows fed both types of SO.

Key words: Conjugated linoleic acid. Oleic acid. Pennisetum purpureum. Rumenic acid. TMR.

\section{Resumo}

O estudo foi realizado em delineamento de blocos ao acaso, em esquema fatorial $2 \times 2$, para avaliar, durante 21 dias, as mudanças no perfil de ácidos graxos (AG) do plasma e leite de vacas Holandês x Gir (444 \pm 84 kg; $75 \pm 31$ dias em lactação; $15,4 \pm 4,8 \mathrm{~kg} \mathrm{dia}^{-1}$ de leite), recebendo dietas à base de $600 \mathrm{~g} \mathrm{~kg}^{-1}$ de capimelefante picado, suplementadas com $45 \mathrm{~g} \mathrm{~kg}^{-1}$ de óleo de girassol (OG), na base da matéria seca. Foram avaliados dois tipos de OG: com alto teor de ácido oleico/baixo teor de ácido linoleico $(\mathrm{HO})$ e com teores médios dos ácidos oleico e linoleico (MO). Os concentrados com OG foram fornecidos separadamente da forragem, duas vezes ao dia (TAD), ou como parte de uma dieta completa (TMR). Utilizando modelos mistos, as alterações temporais $(P<0,05)$ foram analisadas por meio de seis, quatro e sete medidas repetidas no tempo para consumo de $A G$ e perfil de $A G$ no plasma e no leite, respectivamente. As vacas que receberam OG HO consumiram mais ácido oleico, e maiores consumos dos ácidos linoleico e $\alpha$-linolênico foram observados nas que receberam OG MO. Plasma com maior teor de ácido vacênico foi observado nas vacas que receberam concentrado $T A D$, enquanto que as que receberam OG MO apresentaram plasma com maiores teores dos ácidos vacênico e rumênico. Em função do dia, houve aumento linear nos consumos dos ácidos oleico e linoleico, nos teores plasmáticos dos ácidos oleico, vacênico e linoleico, e no teor de ácido linoleico no leite, e houve ajuste quadrático para os teores dos ácidos palmítico, oleico, vacênico e rumênico no leite. Em comparação com as vacas alimentadas com TMR, o leite obtido entre os dias 13 e 17 das que receberam concentrado TAD apresentou perfil de AG mais nutricionalmente desejável para a saúde humana, com menor teor de AG hipercolesterolêmicos e maiores teores dos ácidos oleico, rumênico e vacênico. Entre os dias 15 e 16, os teores dos ácidos vacênico e rumênico no leite das vacas que receberam OG MO foi $81 \%$ maior que o das que receberam OG HO, as quais, no dia 14, apresentaram teor de ácido oleico 14\% maior. O leite produzido entre os dias 13 e 14 apresentou o menor teor de AG hipercolesterolêmicos.

Palavras-chave: Ácido linoleico conjugado. Ácido oleico. Ácido rumênico. Pennisetum purpureum. TMR. 


\section{Introduction}

Diets of lactating cows based on tropical forage supplemented with vegetable oils rich in linoleic acid (cis-9, cis-12 C18:2), such as soybean or sunflower oil (SO), reduce the milk fat contents of lauric (C12:0), myristic (C14:0) and palmitic (C16:0) acids. In addition, these diets simultaneously increase the contents of oleic (cis-9 C18:1), vaccenic (trans-11 C18:1) and rumenic acids (cis-9, trans-11 CLA) (Ribeiro, Lopes, Rodriguez, Gama, \& Morenz, 2018; Lopes et al., 2019). These changes in fatty acid (FA) composition are considered important improvements in the nutritional quality of milk fat (Bernard et al., 2018). However, supplementation with these vegetable oils also promotes an increase in the milk fat content of several rumen-derived FA intermediates of ruminal linoleic and $\alpha$-linolenic acids (cis-9, cis-12, cis-15 C18:3) via biohydrogenation $(\mathrm{BH})$ reactions. Depending on the position and number of double bonds in rumen-derived FAs with trans configurations, they may promote milk fat depression (MFD), reducing the milk fat content (Ribeiro et al., 2018; Lopes et al., 2019). Among these FAs, trans-10 C18:1; trans-10, cis-12 CLA; and trans-9, cis-11 CLA are associated with the inhibition of lipogenesis in the cow mammary gland (Shingfield, Bernard, Leroux, \& Chilliard, 2010; Bernard et al., 2018). All these changes in the FA composition of milk are time-dependent and are closely associated with the adaptation of the rumen microbiota to the characteristics of the diet (Rico, Holloway, \& Harvatine, 2015a). The rumen microbiome is quite sensitive to dietary risk factors for MFD. Then, in response to reductions in the ruminal $\mathrm{pH}$ promoted by the fermentability of the diet, as well as by the load of unsaturated FAs reaching the rumen, changes in the rate, extent and pathways of the ruminal $\mathrm{BH}$ of these FAs can be expected (Fuentes, Calsamiglia, Cardozo, \& Vlaeminck, 2009; Rico et al., 2015a; Rico, Preston, Risser, \& Harvatine, 2015b).

In addition, an understanding of the dynamics of the changes in the FA profiles in plasma and on de novo FA synthesis and stearoyl-CoA delta-9 desaturase (SCD) activity in the mammary gland in response to dietary lipid supplementation is also relevant because the FAs incorporated into milk triacylglycerol are derived from the uptake of preformed FAs from peripheral circulation and FA synthesis in mammary secretory cells (Shingfield et al., 2010; Bernard et al., 2018).

Thus, in the present trial, two types of SO with contrasting levels of oleic and linoleic acids and two methods of concentrate feeding (twice a day separately from forage or as part of a TMR) were used to study the dynamics of the short-term changes in plasma and milk FA profiles of cows fed elephant grass-based diets. We hypothesized that fluctuations in the rumen $\mathrm{pH}$ throughout the day related to the methods of concentrate feeding (National Research Council [NRC], 2001; Lopes, Ribeiro, Rodriguez, Gama, \& Morenz, 2020) associated with changes in the rate, extent and pathways of the ruminal $\mathrm{BH}$ of FAs of each type of SO (oleic versus linoleic acid) could result in differences and variations between treatments regarding the FA profile in the plasma and milk of cows (Jacobs et al., 2011).

Theeffects of theSOtypesandmethods of concentrate feeding on rumen fermentation and degradation, intake of nutrients, plasma contents of metabolites and FAs, milk yield and composition, with a particular emphasis on the FA profile, have already been discussed in detail in a companion paper (Lopes et al., 2020). 
The aim of this study was to evaluate the short-term changes in the fatty acid composition of plasma and milk fat from Holstein x Gyr cows fed chopped elephant grass-based diets containing two types of sunflower oil associated with two methods of concentrate feeding.

\section{Materials and Methods}

The study was carried out at Embrapa Dairy Cattle (Coronel Pacheco, MG, Brazil) from February to March 2011. All of the experimental procedures with animals were conducted according to Embrapa Dairy Cattle guidelines for animal care and use in research. Thirty-two primiparous dairy cows $(444 \pm 84$ $\mathrm{kg}$ ) with genetic compositions varying from $1 / 2$ to $15 / 16$ Holstein $x$ Gyr with $75 \pm 31$ days in milk and producing $15.4 \pm 4.8 \mathrm{~kg} \mathrm{day}^{-1}$ of milk at the beginning of the study were used in a randomized block design experiment. The cows were homogeneously distributed in eight blocks based on milk yield, days in milk, body weight and genetic composition. The experiment was carried out in a $2 \times 2$ factorial arrangement and aimed to evaluate two types of sunflower oil (SO) associated with two methods of concentrate feeding. The types of SO differed by presenting contrasting levels of oleic and linoleic acids: high oleic/

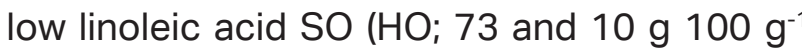
FA, respectively) and medium oleic/medium

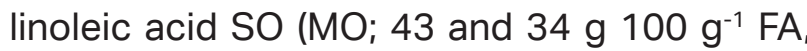
respectively). The types of SO were mixed with other concentrate feeds (ground corn, soybean meal, citrus pulp, and mineral/vitamin supplement). The concentrates containing HO SO or MO SO were supplied separately from forage twice a day after the two milkings (TAD) or as part of a total mixed ration (TMR).
Thus, the four treatments evaluated were TMR-HO, TMR-MO, TAD-HO and TAD-MO. The experiment lasted for 35 days. There was a pre-experimental period of 14 days, when all the cows received the same diet supplied as a TMR based on $600 \mathrm{~g} \mathrm{~kg}^{-1}$ chopped elephant grass supplemented with $400 \mathrm{~g} \mathrm{~kg}^{-1}$ nonlipid concentrate (DM basis). From the $15^{\text {th }}$ to $35^{\text {th }}$ days of the experiment, the cows received the experimental diets.

The experimental diets were formulated (DM basis) with $600 \mathrm{~g} \mathrm{~kg}^{-1}$ chopped elephant grass, $80 \mathrm{~g} \mathrm{~kg}^{-1}$ ground corn, $180 \mathrm{~g} \mathrm{~kg}^{-1}$ soybean meal, $80 \mathrm{~g} \mathrm{~kg}^{-1}$ citrus pulp, $45 \mathrm{~g} \mathrm{~kg}^{-1} \mathrm{SO}$ (Triângulo Alimentos Ltda., Itápolis, SP, Brazil), and $15 \mathrm{~g} \mathrm{~kg}^{-1}$ mineral/vitamin supplement (Top Milk Núcleo ${ }^{\circledR} ;$ Matsuda, Álvares Machado, SP, Brazil). The elephant grass was cut (70 to 90 days of growth) every two days and chopped daily. The concentrates were prepared weekly to avoid lipid peroxidation and were formulated as follows (on a DM basis): $199 \mathrm{~g} \mathrm{~kg}^{-1}$ ground corn, $450 \mathrm{~g} \mathrm{~kg}^{-1}$ soybean meal, $199 \mathrm{~g} \mathrm{~kg}^{-1}$ citrus pulp, $111 \mathrm{~g} \mathrm{~kg}^{-1} \mathrm{SO}$ and $41 \mathrm{~g} \mathrm{~kg}^{-1}$ mineral/vitamin supplement. The chemical composition of elephant grass and concentrates, as well the FA composition of the $\mathrm{HO} \mathrm{SO}-$ and $\mathrm{MO}$ SOdiets, and the ingredients of the diets have already been presented in a companion paper (Lopes et al., 2020).

The cows were collectively lodged in a free stall with available water and a mineral mix. The diets were supplied ad libitum (10\% of leftovers) in troughs equipped with electronic gates (American Calan Inc., Northwood, NH, USA) for individual control of feed intake. For the TMR diets, the roughage and concentrate were weighed, mixed and distributed individually in the troughs once a day after the morning milking using a mixer/dispenser vehicle (Calan Super Data Ranger; American Calan Inc.). In the 
TAD diets, the daily amount of concentrates was divided equally and supplied separately from forage twice a day after the morning and afternoon milkings. In the morning, the concentrate was supplied in the trough, and after its consumption, forage was placed in the trough. In the afternoon, before supplying the concentrate, the forage that was in the trough was removed, and after the cow consumed all the concentrate, the forage was returned to the trough.

Cows were milked twice daily $(06 \mathrm{hO0}$ and 14h00), and eight milk samples were taken throughout the experiment. The first sampling was performed the day before the beginning of the experimental diet supply (Day 0), when all the cows received the preexperimental diet. Then, milk samples were collected on the first day from the beginning of the supply of the experimental diets (Day 1) and at 2, 3, 6, 9, 15 and 21 days. On each day of milk collection, two replicate milk samples (50 $\mathrm{mL}$ ) were collected (2/3 at the morning milking $+1 / 3$ at the afternoon milking). The first samples were stored in bottles with a bronopol preservative and were analyzed for fat by medium infrared spectrometry (Bentley 2300; Bentley Instruments, Inc., Chaska, MN, USA) at the Milk Quality Laboratory of Embrapa Dairy Cattle (Juiz de Fora, MG). The second samples were stored in bottles without the preservative, frozen, subsequently thawed, and analyzed by GC at the Laboratory of Chromatography of Embrapa Dairy Cattle as described by Mourthé et al. (2019).

Blood samples were collected the day before the beginning of the experimental diet supply (Day 0) and at days 3, 9, 15, and 21 of the experimental period. Blood samples were collected via coccygeal venipuncture using test tubes (Vacutainer; Becton-
Dickinson, Rutherford, NJ, USA) containing the anticoagulant EDTA. The samples were immediately centrifuged at $1,500 \times \mathrm{g}$ for $15 \mathrm{~min}$, and plasma $(2 \mathrm{~mL})$ was stored in tubes $\left(-20^{\circ} \mathrm{C}\right)$ until analysis of the plasma FA composition by GC according to the one-step transmethylation procedure proposed by Masood, Stark and Salem (2005).

Temporal changes were analyzed by the MIXED procedure of SAS software $(P<0.05)$ using eight (Day $=1,3,6,9,12,15,18$ and 21), six (Day = 1, 3, 6, 9, 15 and 21), four (Day = 3, 9, 15 and 21) and seven (Day = 1, 2, 3, 6, 9, 15 and 21 ) repeated measures over time of the milk fat content, FA intake, plasma and milk FA composition, respectively. Data collected on the last day of the pre-experimental period (Day 0) were used for covariate adjustments. Method of concentrate feeding (M), type of SO (O), sampling time (Day), and their interactions were considered fixed effects, while the nested repetition (cow) of $\mathrm{M}$ and $\mathrm{O}$, as well as errors, were random effects. The choice of the covariance matrix was based on the Akaike information criterion. Linear and quadratic regressions were performed as a function of day using the values of the LS means of the variables obtained in the MIXED procedure. Pearson's correlation and regression studies were performed using the CORR and REG procedures of SAS, respectively.

\section{Results and Discussion}

Thep-values of the main effects, namely, the method of concentrate feeding (M), type of SO (O) and sampling time (Day), in addition to all the interactions between these factors, are shown in Tables 1 and 2. In general, as can be expected in this type of study, there were many significant $(P<0.05)$ bilateral interactions $\left(M^{*} O\right.$, 
Day ${ }^{*} \mathrm{M}$ and $\left.\mathrm{Day}^{*} \mathrm{O}\right)$, with the triple interaction $\left(\mathrm{M}^{*} \mathrm{O}^{*}\right.$ Day) being significant $(\mathrm{P}<0.05)$ only for the milk fat contents of arachidonic (cis-5, cis8, cis-11, cis-14 C20:4) and myristic acids. Due to all these interactions, few variables showed main effects totally independent from each other. The Day effect was highly significant $(P<0.0001)$ for all variables (Tables 1 and 2$)$, except for the plasma odd- and branchedchain FA (OBCFA) content $(P=0.1639$; Table 1). According to the objective of this study, when significant, the results of the Day $\mathrm{M}$ and Day*O interactions were prioritized, especially if the respective $M$ and $O$ effects were also significant $(P<0.05)$. The effects of the $\mathrm{M}, \mathrm{O}$ and $M * O$ interactions have already been discussed in detail in the companion paper (Lopes et al., 2000). On the other hand, for specific variables that simultaneously presented significant $(P<0.05) M * O, D a y * M$ and Day*O interactions, the results were discussed within the scope of the experimental treatments, i.e., TMR-HO, TMR-MO, TAD-HO and TAD-MO.

There were effects of $M(P=0.0097)$ and $\mathrm{O}(\mathrm{P}=0.0146)$ on DM intake (Table 1). On days 1 and 3, TMR-fed cows presented a higher
$(P<0.05)$ DM intake than the TAD-fed cows, but from day 6 onwards, the DM intake was similar $(P>0.05)$ for both methods (Figure 1a). On days 1 and 21, HO SO-fed cows presented a higher $(\mathrm{P}<0.05) \mathrm{DM}$ intake than MO SO-fed cows, while on the other days, the DM intake was similar $(P>0.05)$ between oils (Figure 2a). There were linear increases $(P<0.05)$ in the $D M$ intake of TMR-, TAD-, HO SO- and MO SO-fed cows as a function of day. There was an effect of $O$ $(P<0.0001)$ but no effect $(P>0.05)$ of $M$ on the dietary intake of oleic, linoleic and $\alpha$-linolenic acids (Table 1). However, because of the effect $(P \leq 0.0001)$ of the Day*M interaction (Table 1), TMR-fed cows presented a higher $(P<0.05)$ intake of oleic, linoleic and $\alpha$-linolenic acids on day 1. HO SO-fed cows presented a higher $(P<0.05)$ oleic acid intake (Figure $2 b)$, while MO SO-fed cows presented a higher $(P<0.05)$ linoleic and $\alpha$-linolenic acid intake (Figure $2 \mathrm{c}$ ). As a function of day, there were linear increases $(P=0.0040)$ in oleic and linoleic acid intake, while the quadratic regressions were adjusted for $\alpha$-linolenic acid intake for TMR-, TAD-, HO SO- and MO SO-fed cows (Figures $1 \mathrm{c}$ and $2 \mathrm{c}$ ). 
Table 1

$P$-values of fixed effects evaluated for milk fat content, dry matter and fatty acid (FA) intake, apparent transfer of ingested FA into milk, and plasma FA content

\begin{tabular}{|c|c|c|c|c|c|c|c|}
\hline Item & $\begin{array}{l}\text { Method } \\
\text { (M) }\end{array}$ & $\begin{array}{l}\text { Oil } \\
\text { (O) }\end{array}$ & $\mathrm{M}^{*} \mathrm{O}$ & Day & $\begin{array}{l}\text { Day } \\
{ }^{*} \mathrm{M}\end{array}$ & $\begin{array}{l}\text { Day } \\
{ }^{*} \mathrm{O}\end{array}$ & $\begin{array}{l}\text { Day } \\
{ }^{*} \mathrm{M}^{*} \mathrm{O}\end{array}$ \\
\hline Milk fat content (\%) & 0.2537 & 0.9458 & 0.5919 & $<0.0001$ & 0.6436 & 0.7001 & 0.3900 \\
\hline Dry matter intake & 0.0097 & 0.0146 & 0.6980 & $<0.0001$ & 0.0007 & 0.6926 & 0.2241 \\
\hline \multicolumn{8}{|l|}{ FA intake (g day-1) } \\
\hline cis-9 C18:1 & 0.2263 & $<0.0001$ & 0.7369 & $<0.0001$ & $<0.0001$ & 0.5592 & 0.0625 \\
\hline cis-9, cis-12 C18:2 & 0.2226 & $<0.0001$ & 0.7322 & $<0.0001$ & $<0.0001$ & 0.1439 & 0.0622 \\
\hline cis-9, cis-12, cis-15 C18:3 & 0.3233 & $<0.0001$ & 0.8714 & $<0.0001$ & 0.0001 & 0.2610 & 0.1153 \\
\hline \multicolumn{8}{|c|}{ Apparent transfer of ingested FAs (g day ${ }^{-1}$ ) into milk (g day ${ }^{-1}$ ) } \\
\hline cis-9 C18:1 & 0.0042 & $<0.0001$ & 0.9985 & $<0.0001$ & 0.1085 & $<0.0001$ & 0.2195 \\
\hline cis-9, cis-12 C18:2 & 0.0005 & $<0.0001$ & 0.5965 & $<0.0001$ & 0.0029 & $<0.0001$ & 0.1088 \\
\hline cis-9, cis-12, cis-15 C18:3 & $<0.0001$ & 0.0053 & 0.5891 & $<0.0001$ & $<0.0001$ & 0.0042 & 0.3608 \\
\hline \multicolumn{8}{|c|}{ Plasma FA content (g $\left.100 \mathrm{~g}^{-1} \mathrm{FA}\right)$} \\
\hline C12:0 & 0.4170 & 0.0037 & 0.7218 & $<0.0001$ & 0.4050 & 0.4838 & 0.3067 \\
\hline C14:0 & 0.0909 & 0.3547 & 0.6241 & $<0.0001$ & 0.2186 & 0.5141 & 0.1702 \\
\hline C16:0 & 0.3414 & 0.1807 & 0.4324 & $<0.0001$ & 0.7054 & 0.8003 & 0.8192 \\
\hline C18:0 & 0.9993 & 0.2458 & 0.1739 & $<0.0001$ & 0.7643 & 0.0101 & 0.6321 \\
\hline trans-9 C18:1 & 0.6735 & $<0.0001$ & 0.8208 & $<0.0001$ & 0.0087 & 0.0295 & 0.8989 \\
\hline trans-10 C18:1 & 0.6885 & 0.1640 & 0.6458 & $<0.0001$ & 0.0017 & 0.2766 & 0.9989 \\
\hline trans-11 C18:1 & $<0.0001$ & $<0.0001$ & 0.0701 & $<0.0001$ & 0.5627 & 0.3093 & 0.9337 \\
\hline cis-9 C18:1 & 0.6924 & $<0.0001$ & 0.5985 & $<0.0001$ & 0.2928 & $<0.0001$ & 0.9112 \\
\hline cis-9, cis-12 C18:2 & 0.9638 & 0.0001 & 0.0084 & $<0.0001$ & 0.0212 & 0.0073 & 0.2524 \\
\hline cis-9, cis-12, cis-15 C18:3 & 0.1057 & 0.0524 & 0.2751 & $<0.0001$ & 0.0915 & 0.4050 & 0.1482 \\
\hline cis-9, trans-11 CLA & 0.3303 & $<0.0001$ & 0.8433 & $<0.0001$ & 0.2159 & 0.2597 & 0.1603 \\
\hline trans-9, cis-11 CLA & 0.5068 & 0.2110 & 0.6460 & $<0.0001$ & 0.6313 & 0.8596 & 0.9168 \\
\hline trans-10, cis-12 CLA & 0.7426 & 0.5846 & 0.5478 & $<0.0001$ & 0.4333 & 0.1213 & 0.4303 \\
\hline C20:4 ARA ${ }^{b}$ & 0.0169 & 0.4338 & 0.3528 & $<0.0001$ & 0.6106 & 0.1922 & 0.6330 \\
\hline C20:5 EPA & 0.4462 & 0.7653 & 0.9507 & $<0.0001$ & 0.1822 & 0.3786 & 0.2099 \\
\hline $\mathrm{C} 22: 6 \mathrm{DHA}^{\mathrm{d}}$ & 0.6921 & 0.6520 & 0.7551 & $<0.0001$ & 0.2451 & 0.2879 & 0.1279 \\
\hline$\Sigma$ OBCFA $^{\mathrm{e}}$ & 0.0024 & 0.2998 & 0.7516 & 0.3821 & 0.1086 & 0.7076 & 0.1390 \\
\hline
\end{tabular}

akg $100 \mathrm{~kg}^{-1}$ of body weight; ${ }^{\mathrm{B}}$ Arachidonic acid (cis-5, cis-8, cis-11, cis-14 C20:4); 'Eicosapentaenoic acid (cis-5, cis8, cis-11, cis-14, cis-17 C20:5); 'Docosahexanoic acid (cis-4, cis-9, cis-10, cis-13, cis-16, cis-19 C20:6); 'Odd- and branched-chain $\mathrm{FA}=$ anteiso $\mathrm{C} 15: 0+$ anteiso $\mathrm{C} 17: 0+$ iso $\mathrm{C} 15: 0+$ iso $\mathrm{C} 16: 0+$ iso $\mathrm{C} 17: 0+\mathrm{C} 13: 0+\mathrm{C} 15: 0+\mathrm{C} 17: 0+$ cis-9 $\mathrm{C} 17: 1+\mathrm{C} 21: 0+\mathrm{C} 23: 0$. 
There were effects $(P<0.01)$ of $M$ and $\mathrm{O}$ on the apparent transfer of ingested oleic, linoleic and $\alpha$-linolenic acids into milk (Table 1 ). There was no linear or quadratic adjustment $(P>0.05)$ for the apparent transfer of ingested oleic as a function of day for TMR-, TAD-, HO SO- and MO SO-fed cows. On days 1 and 9, TAD-fed cows presented a higher $(P<0.05)$ apparent transfer of oleic acid than TMR-fed cows, with a similar $(P>0.05)$ apparent transfer between methods on the other days. For the apparent transfer of ingested linoleic and $\alpha$-linolenic acids, linear reductions $(P<0.05)$ were observed as a function of day for TMR-, TAD-, HO SO- and MO SO-fed cows (Figures
$1 d$ and $2 d$ ). Overall, in the comparison within days, the apparent transfer of ingested linoleic and $\alpha$-linolenic acids was higher $(P<0.05)$ for TAD-fed cows (Figure 1d) than TMR-fed cows. The apparent transfer of ingested oleic acid was always higher $(\mathrm{P}<0.05)$ for $\mathrm{MO} \mathrm{SO}-\mathrm{fed}$ cows (data not shown), while the apparent transfer of ingested linoleic acid was always higher $(\mathrm{P}<0.05)$ for $\mathrm{HO}$ SO-fed cows (Figure $2 d)$. Between the oils, a similarity $(P>0.05)$ was observed for the apparent transfer of ingested $\alpha$-linolenic acid, except on day 9 , when $\mathrm{HO}$ SO-fed cows showed higher $(P<0.05)$ values (Figure 2d) than MO SO-fed cows.
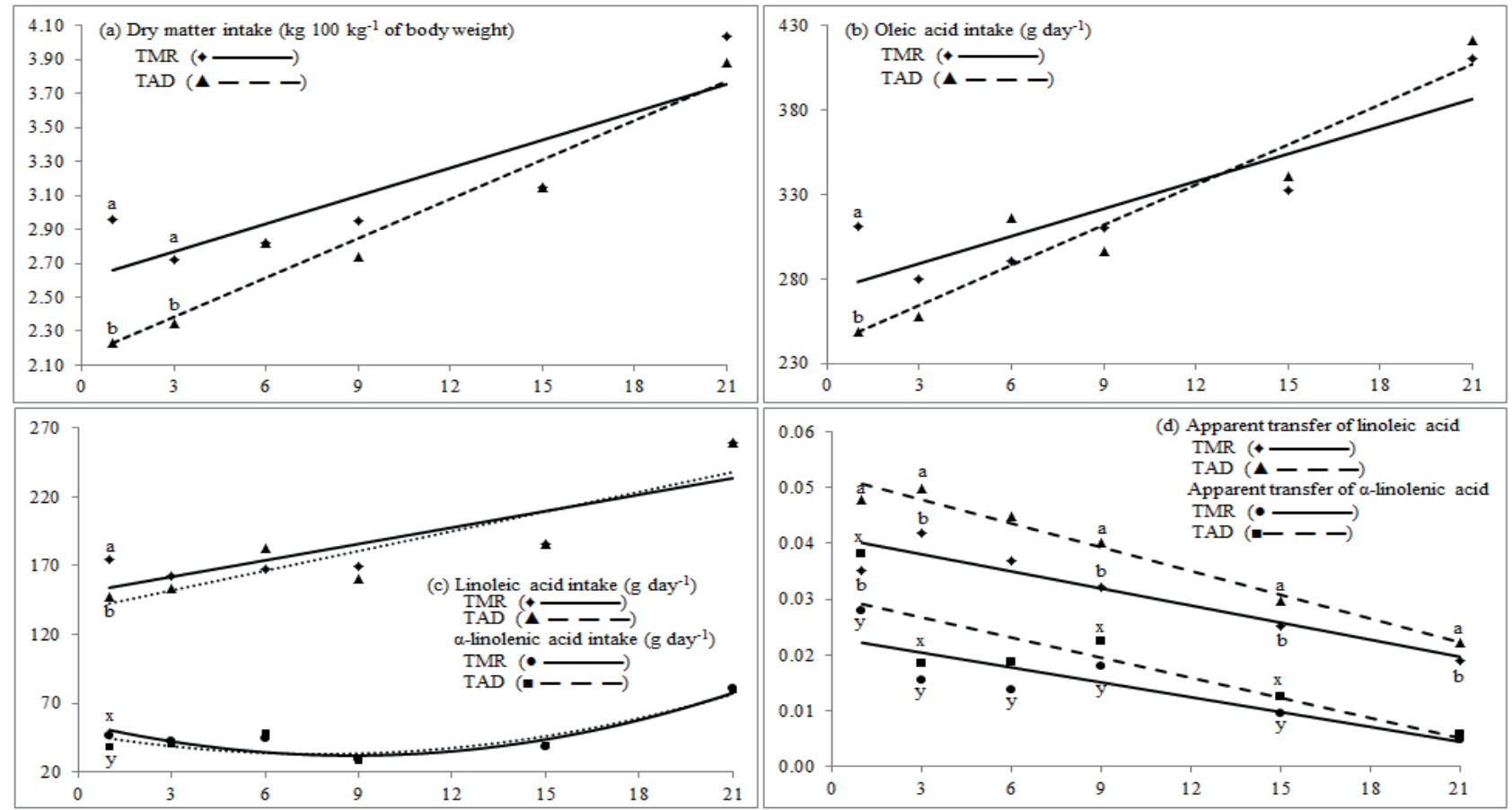

Figure 1. Effect of day on dry matter and fatty acid (FA) intake and the apparent transfer of ingested FAs into milk in Holstein $x$ Gyr cows fed chopped elephant grass-based diets with $45 \mathrm{~g} \mathrm{~kg}^{-1} \mathrm{DM}$ high or medium oleic acid sunflower oil supplied in a concentrate twice a day (TAD) or as part of a TMR (TMR). Within the same day, different letters indicate differences $(P<0.05)$ between TMR and TAD. 


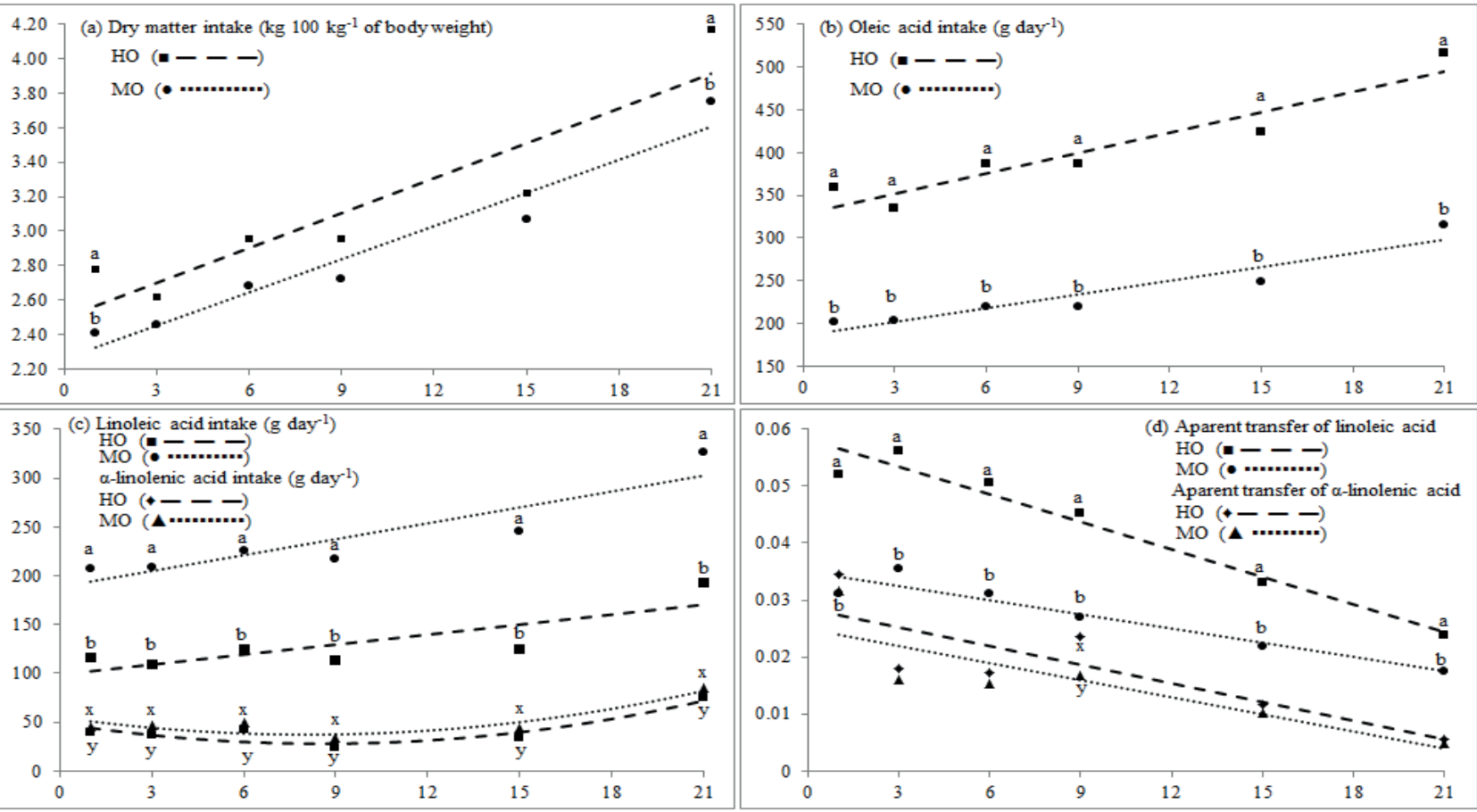

Figure 2. Effect of day on dry matter and fatty acid (FA) intake and the apparent transfer of ingested FAs into milk in Holstein $x$ Gyr cows fed chopped elephant grass-based diets with $45 \mathrm{~g} \mathrm{~kg}^{-1} \mathrm{DM}$ high (HO) or medium oleic (MO) acid sunflower oil (SO) supplied in a concentrate twice a day (TAD) or as part of a TMR (TMR). Within the same day, different letters indicate differences $(P<0.05)$ between HO SO and MO SO.

There was no effect $(\mathrm{P}>0.05)$ of $\mathrm{M}$ or $\mathrm{O}$ on the milk fat content (Table 1), and a quadratic regression was adjusted as a function of day $(P<0.0001)$, where the highest content $(3.87 \%)$ was estimated to occur close to day 10 . The average milk fat contents were $3.65 \%, 3.77 \%$, $3.71 \%$ and $3.70 \%$ for TMR-, TAD, HO SO- and MO SO-fed cows, respectively.

The FAs present in higher contents in plasma were stearic, linoleic, palmitic, oleic, $\alpha$-linolenic and vaccenic acids. There was an effect $(P<0.05)$ of $M$ only on the plasma contents of vaccenic and arachidonic acids and OBCFA (Table 1). TAD-fed cows presented a higher $(P<0.05)$ plasma vaccenic acid content (Figure 3a), and TMR-fed cows presented higher $(P<0.05)$ levels of arachidonic acid and OBCFA (data not shown). There were no effects $(P>0.05)$ of $M$ and $O$ on the plasma contents of myristic, palmitic, stearic, trans-10 C18:1, $\alpha$-linolenic, trans-9, cis-11 CLA, trans-10, cis12 CLA, EPA (eicosapentaenoic acid; cis-5, cis-8, cis-11, cis-14, cis-17 C20:5) and DHA (docosahexanoic acid; cis-4, cis-9, cis-10, cis13, cis-16, cis-19 C20:6). 

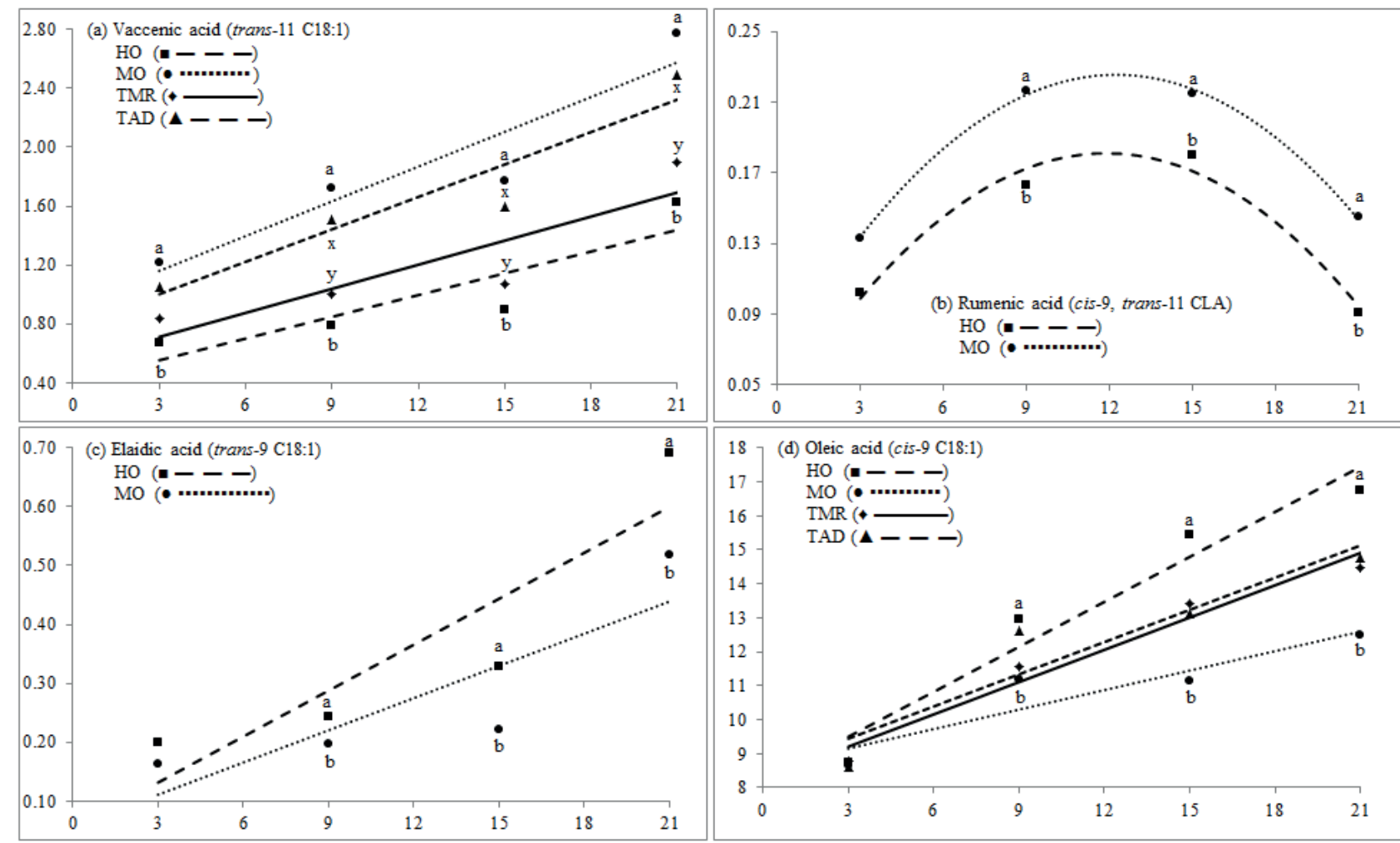

Figure 3. Effect of day on fatty acid contents (g $100 \mathrm{~g}^{-1} \mathrm{FA}$ ) in plasma of Holstein $x$ Gyr cows fed chopped elephant grass-based diets with $45 \mathrm{~g} \mathrm{~kg}^{-1} \mathrm{DM}$ high (HO) or medium (MO) oleic acid sunflower oil (SO) supplied in a concentrate twice a day (TAD) or as part of a TMR (TMR). Within the same day, different letters indicate differences $(P<0.05)$ between TMR versus TAD and between HO SO versus MO SO.

There was an effect $(P<0.01)$ of $O$ on the plasma contents of lauric, vaccenic, rumenic, elaidic, oleic and linoleic acids (Table 1). MO SO-fed cows presented higher $(P<0.05)$ plasma vaccenic and rumenic acid contents (Figures $3 a$ and $3 b$ ). For both oils, the plasma content of vaccenic acid increased linearly $(\mathrm{P}<0.0001)$ as a function of day (Figure 3a), and the quadratic regression was adjusted $(P<0.0001)$ for rumenic acid, for which the highest levels $\left(0.181\right.$ and $0.226 \mathrm{~g} 100 \mathrm{~g}^{-1} \mathrm{FA}$, respectively, for HO SO- and MO SO-fed cows) were estimated to occur around day 12 (Figure 3b). HO SO-fed cows presented a higher
$(\mathrm{P}<0.05)$ plasma lauric acid content than $\mathrm{MO}$ SO-fed cows. For elaidic and oleic acids, as a result of the Day*O interaction $(P<0.05$; Table $1)$, their plasma contents were higher $(P<0.05)$ in HO SO-fed cows on days 9, 15 and 21 and similar $(P>0.05)$ to those in MO SO-fed cows on day 3 (Figures $3 c$ and $3 d$ ). For both oils, the plasma contents of elaidic and oleic acids increased linearly $(P<0.0001)$ as a function of day (Figures 3c and 3d).

The $M^{*} O$, Day*Mand Day*O interactions were significant $(\mathrm{P}<0.05)$ for the plasma linoleic acid content (Table 1). For this reason, the results of this FA are presented within the 
scope of the experimental treatments (Figure $4 a)$. On day 3 , the plasma linoleic acid contents were similar $(P>0.05)$ among treatments, but on days 15 and 21, cows that received the TAD-MO treatment showed higher $(P<0.05)$ plasma contents of linoleic acid than those that received the TMR-MO treatment, while cows that received the TMR-HO and TAD$\mathrm{HO}$ treatments showed equivalent $(P>0.05)$ results every day (Figure $4 a$ ). Regardless of the treatment, the linoleic acid plasma content increased linearly $(P<0.0001)$ as a function of day (Figure 4a).
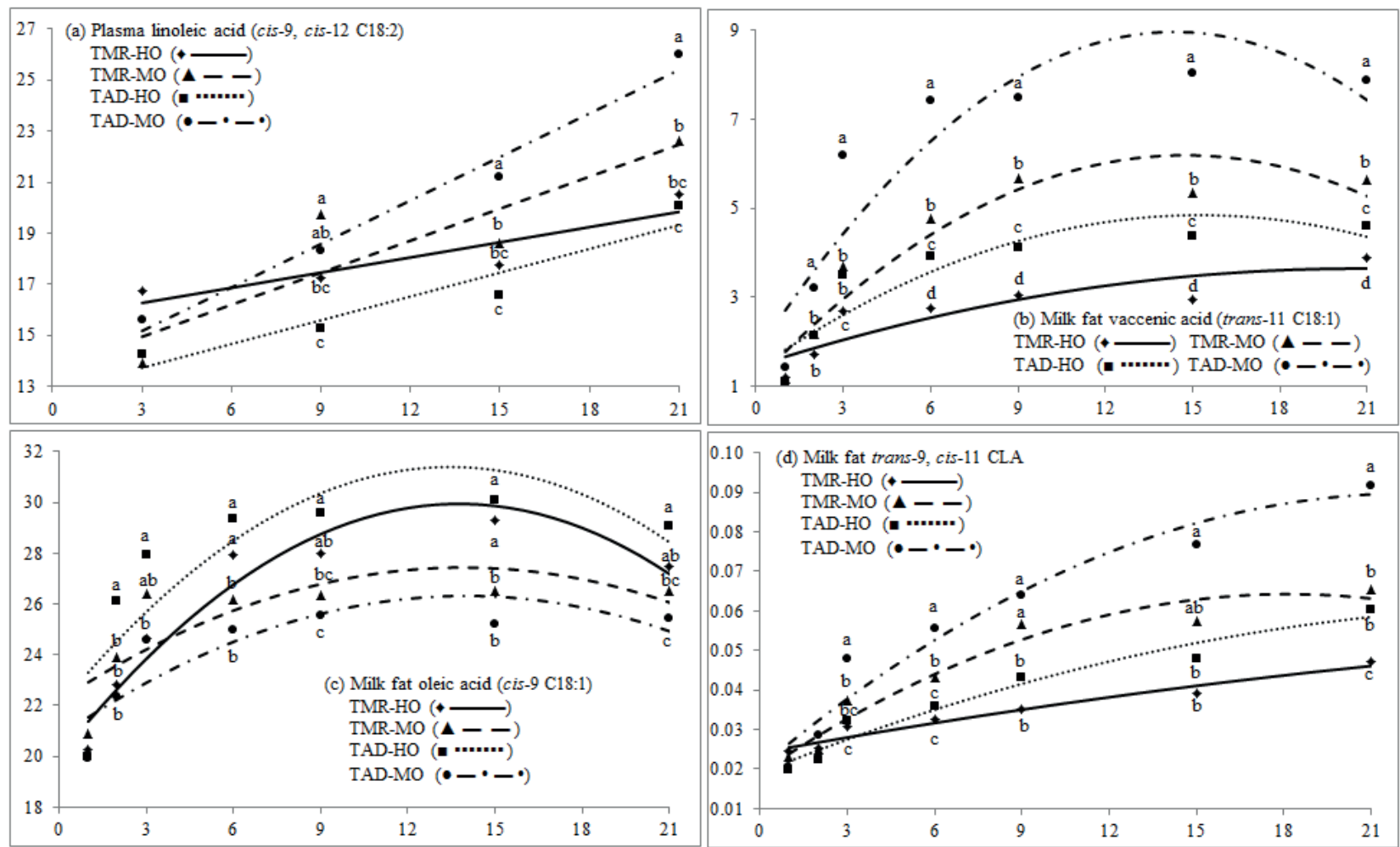

Figure 4. Effect of day on plasma linoleic acid content and on trans-9, cis-11 CLA, vaccenic and oleic acid contents (g $100 \mathrm{~g}^{-1} \mathrm{FA}$ ) in milk fat of Holstein $x$ Gyr cows fed chopped elephant grassbased diets with $45 \mathrm{~g} \mathrm{~kg}^{-1} \mathrm{DM}$ high (HO) or medium oleic (MO) acid sunflower oil supplied in a concentrate twice a day (TAD) or as part of a TMR (TMR). Within the same day, different letters indicate differences $(P<0.05)$ among treatments (TMR-HO, TMR-MO, TAD-HO and TAD-MO). 
Despite the $\mathrm{M}^{*} \mathrm{O}$ interaction $(P=0.0233)$, there was no effect $(P>0.05)$ of $M$ or $\mathrm{O}$ on the sum of the milk fat contents of de novo-synthesized short chain FAs, i.e., $\Sigma \mathrm{C} 4: 0$ + C6:0 + C8:0 + C10:0 (Table 2). As a function of day, a quadratic effect $(\mathrm{P}<0.0001)$ was observed for TMR-, TAD-, HO SO- and MO SOfed cows, with the estimated minimum levels occurring close to day 15 (data not shown). There were effects of $O(P=0.0044)$ and the Day ${ }^{*} O$ interaction $(P=0.0042)$ on the milk fat lauric acid content (Table 2). A quadratic adjustment $(P<0.0001)$ was observed as a function of day, with the estimated minimum levels occurring close to day 14 (data not shown). For the milk fat contents of palmitic acid, the sum of lauric + myristic + palmitic acid ( $\Sigma \mathrm{C} 12: 0-\mathrm{C} 16: 0)$, and stearic acid, there were effects $(P<0.05)$ of the $M, O$, Day* $M$ and Day*O interactions (Table 2). As a function of day, a quadratic effect $(P<0.0001)$ was observed for the milk fat palmitic acid content, with estimated minimum levels occurring around day 13 of $18.825,17.260,16.778$ and

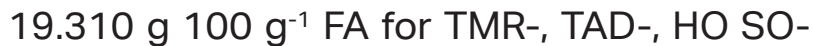
and $\mathrm{MO}$ SO-fed cows, respectively (Figures $5 \mathrm{a}$ and $6 \mathrm{a}$ ). Likewise, there was a quadratic adjustment for $\Sigma \mathrm{C} 12: 0-\mathrm{C} 16: 0$ as a function of day $(P<0.0001)$, with the estimated minimum levels also close to those on the $13^{\text {th }}$ day, with 25.918, 23.989, 24.041 and $25.863 \mathrm{~g} 100$ $\mathrm{g}^{-1}$ FA for TMR-, TAD-, HO SO- and MO SOfed cows, respectively (Figures $5 \mathrm{a}$ and $6 \mathrm{a}$ ). Comparing methods, TMR-fed cows showed higher $(\mathrm{P}<0.05)$ milk fat palmitic acid and ¿C12:0-C16:0 contents on days 3, 6, 9 and 21. For the milk fat stearic acid content, there was no linear or quadratic adjustment $(P>0.05)$ as a function of day for any method or oil. However, from day 3 onwards, HO SO-fed cows showed a higher $(\mathrm{P}<0.05)$ milk fat stearic acid content than MO SO-fed cows. Comparing methods, differences occurred on days 6 and 15, when TMR-fed cows had a higher $(P<0.05)$ milk fat stearic acid content (data not shown). 
Table 2

P-values of fixed effects evaluated for milk fatty acid (FA) content (g $100 \mathrm{~g}^{-1} \mathrm{FA}$ )

\begin{tabular}{|c|c|c|c|c|c|c|c|}
\hline Item & $\begin{array}{l}\text { Method } \\
\text { (M) }\end{array}$ & $\begin{array}{l}\text { Oil } \\
\text { (O) }\end{array}$ & $\mathrm{M}^{*} \mathrm{O}$ & Day & $\begin{array}{l}\text { Day } \\
{ }^{*} \mathrm{M}\end{array}$ & $\begin{array}{l}\text { Day } \\
{ }^{*} \mathrm{O}\end{array}$ & $\begin{array}{l}\text { Day } \\
{ }^{*} \mathrm{M}^{*} \mathrm{O}\end{array}$ \\
\hline C12:0 & 0.5439 & 0.0044 & 0.2628 & $<0.0001$ & 0.1995 & 0.0042 & 0.0773 \\
\hline C14:0 & 0.1033 & 0.0008 & 0.1676 & $<0.0001$ & 0.0383 & 0.0214 & 0.0345 \\
\hline C16:0 & 0.0111 & $<0.0001$ & 0.5987 & $<0.0001$ & $<0.0001$ & 0.0003 & 0.3498 \\
\hline C18:0 & 0.0378 & $<0.0001$ & 0.9058 & $<0.0001$ & 0.0191 & $<0.0001$ & 0.8186 \\
\hline trans-9 C18:1 & 0.3432 & $<0.0001$ & 0.1391 & $<0.0001$ & 0.0016 & $<0.0001$ & 0.2784 \\
\hline trans-10 C18:1 & 0.4410 & 0.0005 & 0.5638 & $<0.0001$ & $<0.0001$ & 0.0669 & 0.8959 \\
\hline trans-11 C18:1 & $<0.0001$ & $<0.0001$ & 0.0196 & $<0.0001$ & $<0.0001$ & $<0.0001$ & 0.1504 \\
\hline cis-9 C18:1 & 0.6172 & $<0.0001$ & 0.0022 & $<0.0001$ & 0.4141 & $<0.0001$ & 0.0646 \\
\hline cis-9, cis-12 C18:2 & 0.3124 & $<0.0001$ & 0.6836 & $<0.0001$ & 0.0468 & 0.0057 & 0.2402 \\
\hline cis-9, cis-12, cis-15 C18:3 & 0.1622 & 0.0402 & 0.6058 & $<0.0001$ & 0.0316 & 0.0267 & 0.3981 \\
\hline cis-9, trans-11 CLA & $<0.0001$ & $<0.0001$ & 0.0894 & $<0.0001$ & $<0.0001$ & $<0.0001$ & 0.1212 \\
\hline trans-9, cis-11 CLA & $<0.0001$ & $<0.0001$ & 0.0411 & $<0.0001$ & $<0.0001$ & $<0.0001$ & 0.5397 \\
\hline trans-10, cis-12 CLA & 0.0698 & $<0.0001$ & 0.1207 & $<0.0001$ & 0.6769 & 0.0044 & 0.3793 \\
\hline C20:4 ARA & 0.5033 & 0.2786 & 0.5625 & $<0.0001$ & 0.0029 & 0.3268 & 0.0470 \\
\hline C20:5 EPA ${ }^{b}$ & 0.8308 & 0.0039 & 0.9538 & $<0.0001$ & 0.0386 & 0.0032 & 0.3814 \\
\hline$\Sigma 4 \leq \mathrm{C} \leq 10$ & 0.7961 & 0.5584 & 0.0233 & $<0.0001$ & 0.0101 & 0.2755 & 0.0721 \\
\hline$\Sigma 12 \leq \mathrm{C} \leq 16$ & 0.0073 & 0.0232 & 0.2498 & $<0.0001$ & 0.0016 & 0.0016 & 0.2957 \\
\hline$\Sigma \mathrm{OBCFA}^{\mathrm{c}}$ & $<0.0001$ & 0.0510 & 0.0787 & $<0.0001$ & 0.0171 & 0.0056 & 0.9252 \\
\hline$\sum$ trans-C18:1 & $<0.0001$ & $<0.0001$ & 0.0553 & $<0.0001$ & 0.0003 & 0.0034 & 0.4933 \\
\hline \multicolumn{8}{|c|}{ Milk desaturase index - obtained according to Kelsey, Corl, Collier and Bauman ( 2003) } \\
\hline$\Delta^{18}$ & 0.0214 & 0.1610 & 0.0560 & $<0.0001$ & 0.0740 & 0.5454 & 0.5122 \\
\hline$\Delta^{\mathrm{CLA}}$ & 0.9102 & 0.6842 & 0.4692 & $<0.0001$ & 0.0736 & 0.0922 & 0.5704 \\
\hline
\end{tabular}

aAraquidonic acid (cis-5, cis-8, cis-11, cis-14 C20:4); 'bicosapentaenoic acid (cis-5, cis-8, cis-11, cis-14, cis-17 C20:5); 'Odd- and branched-chain FA = anteiso C15:0 + iso C14:0 + iso C15:0 + iso C16:0 + iso C17:0 + C5:0 + C7:0 + C9:0 +

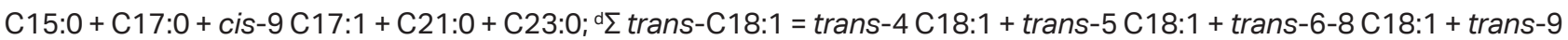
C18:1 + trans-10 C18:1 + trans-11 C18:1 + trans-12 C18:1 + trans-13-14 C18:1 + trans-16 C18:1. 
There was an effect $(P<0.001)$ of $O$ on the milk fat contents of elaidic acid (trans-9 C18:1) and trans-10 C18:1 (Table 2). As a function of day, the quadratic regression $(P<0.0001)$ was adjusted for elaidic acid, with the maximum estimated levels occurring around the $14^{\text {th }}$ day for both oils (data not shown). For trans-10 C18:1, there was no linear or quadratic adjustment $(P>0.05)$ as a function of day for either oil. HO SO-fed cows showed higher $(P<0.05)$ milk fat contents of elaidic acid on day 2, while MO SO-fed cows showed higher $(P<0.05)$ milk fat contents of trans-10 C18:1 on day 3 (data not shown).
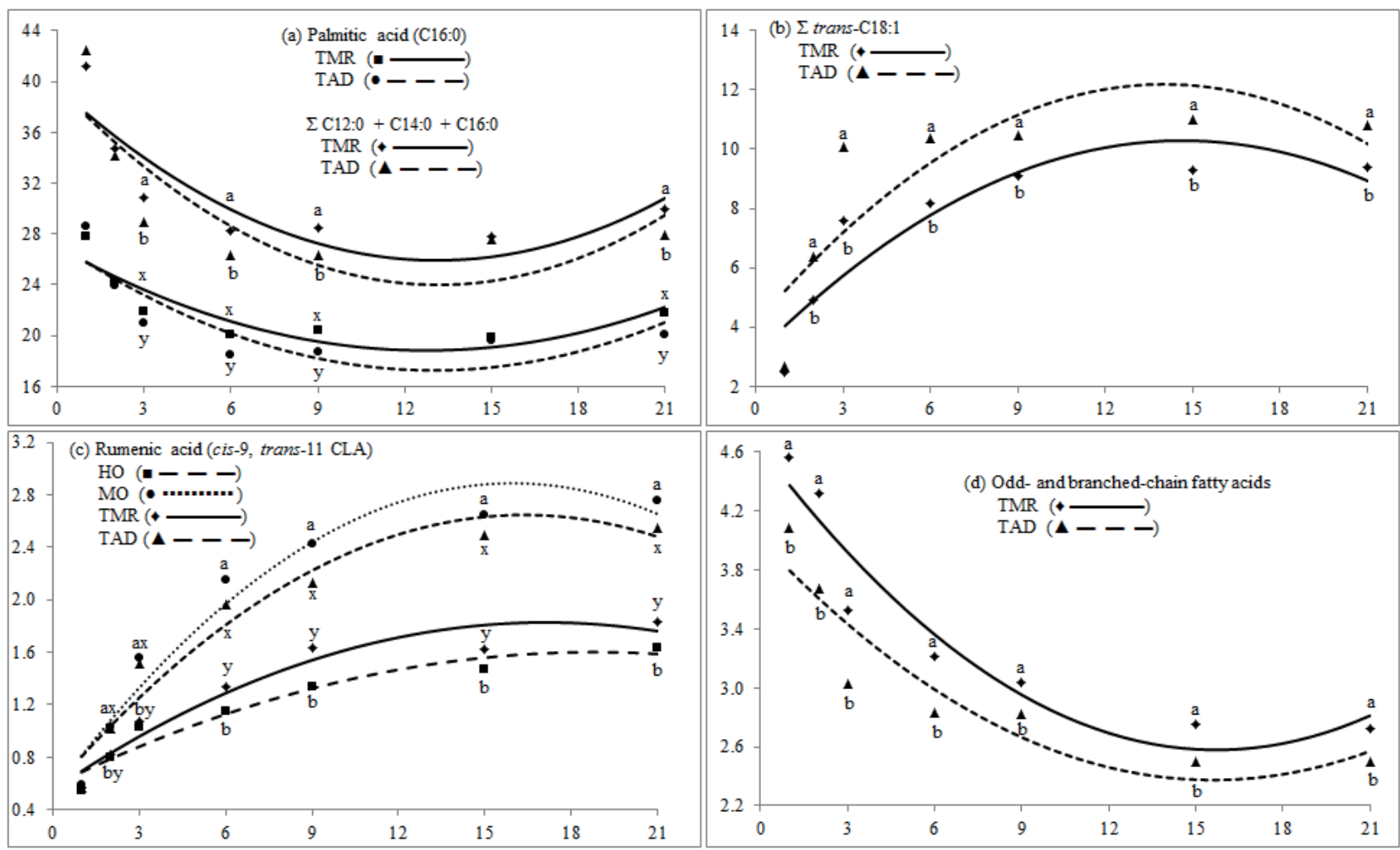

Figure 5. Effect of day on fatty acid contents (g $\left.100 \mathrm{~g}^{-1} \mathrm{FA}\right)$ in milk fat of Holstein $x$ Gyr cows fed chopped elephant grass-based diets with $45 \mathrm{~g} \mathrm{~kg}^{-1} \mathrm{DM}$ high (HO) or medium (MO) oleic acid sunflower oil (SO) supplied in a concentrate twice a day (TAD) or as part of a TMR (TMR). Within the same day, different letters indicate differences $(P<0.05)$ between TMR versus TAD and between HO SO versus MO SO. 

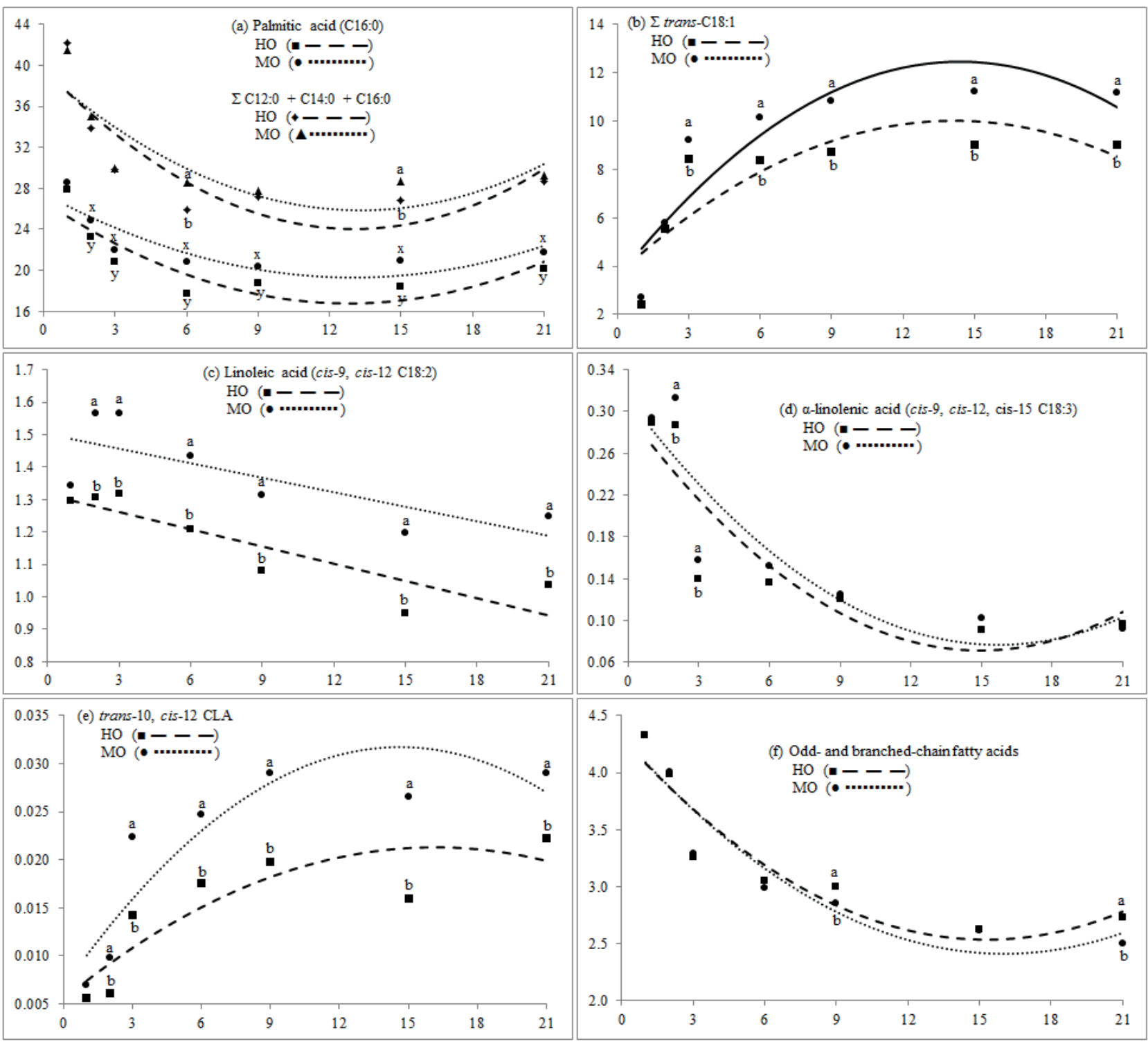

Figure 6. Effect of day on fatty acid contents (g $100 \mathrm{~g}^{-1} \mathrm{FA}$ ) in milk fat of Holstein $x$ Gyr cows fed chopped elephant grass-based diets with $45 \mathrm{~g} \mathrm{~kg}^{-1} \mathrm{DM}$ high (HO) or medium (MO) oleic acid sunflower oil (SO) supplied in a concentrate twice a day (TAD) or as part of a TMR (TMR). Within the same day, different letters indicate differences $(P<0.05)$ between $\mathrm{HO}$ SO and MO SO. 
In response to the $\mathrm{M}^{*} \mathrm{O}$ interaction $(P<0.05$; Table 2$)$, the results regarding the milk fat contents of vaccenic and oleic acids are presented according to the experimental treatments. On day 1 , the treatments showed similar contents $(P>0.05)$ for milk fat vaccenic acid, but from day 6 , the content of milk fat vaccenic acid was in the order TAD-MO > TMR-MO > TAD-HO > TMR-HO $(\mathrm{P}<0.05)$ (Figure 4b). As a function of day, there were quadratic adjustments $(P \leq 0.05)$ for all the treatments, with the maximum estimated milk fat vaccenic acid contents of $3.640,6.192,4.845$ and 8.968 g $100 \mathrm{~g}^{-1}$ FA reached on days 21, 15, 15 and 14, respectively, for the TMR-HO, TMR-MO, TAD-HO and TAD-MO treatments (Figure 4b). On day 1 , the treatments showed similar milk fat oleic acid contents $(P>0.05)$, but from day 6 , the TAD-HO and TMR-HO treatments stood out, being, in general, higher $(\mathrm{P}<0.05)$ than the others (Figure 4c). There were quadratic adjustments as a function of day for all the treatments, with the maximum estimated levels of 29.942, 27.435, 31.397 and 26.320 g $100 \mathrm{~g}^{-1}$ FA reached around the $14^{\text {th }}$ day for the TMR-HO, TMR-MO, TAD-HO and TAD-MO treatments, respectively (Figure $4 \mathrm{c}$ ).

For the milk fat contents of $\Sigma$ trans-C18:1 FAs, there were effects $(P<0.01)$ of the $\mathrm{M}, \mathrm{O}, \mathrm{Day}{ }^{*} \mathrm{M}$ and Day*O interactions (Table 2). On day 1, the milk fat contents of $\Sigma$ trans-C18:1 FAs were similar $(P>0.05)$ between methods (Figure $5 \mathrm{~b}$ ), but thereafter, the milk fat of TAD-fed cows showed higher $(P<0.05)$ contents. Between oils, on days 1 and 2 , there was a similarity $(P>0.05)$, and from then on, MO SO-fed cows showed higher $(P<0.05)$ contents than $\mathrm{HO}$ SO-fed cows. As a function of day, the quadratic regressions $(P<0.0001)$ were adjusted (Figures $5 b$ and $6 b)$, and the maximum estimated milk fat contents of $\Sigma$ trans-C18:1 FAs were achieved close to day 14 for TMR-, TAD-, HO SO- and MO SO-fed cows.

There were effects $(P<0.05)$ of $O$ and the Day ${ }^{*} \mathrm{O}$ interaction (Table 2 ) on the milk fat contents of linoleic and $\alpha$-linolenic acids. As a function of day, the linear regressions $(P<0.05)$ were adjusted for the milk fat linoleic acid content for both oils. On day 1, HO SO- and MO SO-fed cows showed similar ( $P>0.05)$ milk fat contents of linoleic acid, but on day 2 , the levels were always higher $(\mathrm{P}<0.05)$ in $\mathrm{HO}$ SOfed cows (Figure 6c). For the milk fat $\alpha$-linolenic acid content, as a function of day, the quadratic regressions $(P<0.05)$ were adjusted (Figure $6 \mathrm{~d})$. The levels of $\alpha$-linolenic acid were higher $(\mathrm{P}<0.05)$ in MO SO-fed cows on days 2 and 3 and were similar $(P>0.05)$ to those in $\mathrm{HO} S \mathrm{~S}-$ fed cows on the other days. The minimum levels estimated for MO SO-fed cows (day 16) and $\mathrm{HO}$ SO-fed cows (day 15) were 0.077 and

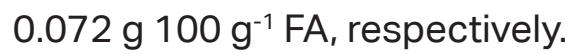

There were effects $(P<0.0001)$ of the $M$, $\mathrm{O}$, Day* $\mathrm{M}$ and Day* ${ }^{*}$ interactions on the milk fat rumenic acid content (Table 2). On day 1, the levels of rumenic acid were similar $(P>0.05)$ according to the comparisons between methods and oils (Figure 5c). From then on, TAD- and MO SO-fed cows always showed higher $(P<0.05)$ levels than TMR- and HO SOfed cows, respectively. There were quadratic adjustments $(P<0.01)$ as a function of day for TMR-, TAD-, HO SO- and MO SO-fed cows, with the maximum estimated levels of 1.828 ,

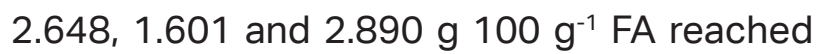
on days 17, 16, 19 and 16, respectively (Figure $5 c)$.

In response to the effects $(P<0.05)$ of the $\mathrm{M}^{*} \mathrm{O}$, Day* $\mathrm{M}$ and Day*O interactions (Table $2)$, the results regarding the milk fat trans-9, 
cis-11 CLA content are presented within the scope of the experimental treatments (Figure $4 d)$. From day 3, the TAD-MO treatment stood out $(P<0.05)$ from the others. TAD-MO-fed cows produced milk with higher $(\mathrm{P}<0.05)$ trans-9, cis-11 CLA content than TMR-MO-fed cows on days 3,6 and 21, while TAD-HO-fed cows produced milk with higher $(P<0.05)$ levels than TMR-HO-fed cows on day 21 (Figure 4d). There were quadratic adjustments $(P<0.01)$ as a function of day for all the treatments, with the maximum milk fat trans-9, cis-11 CLA contents estimated to be achieved on days 48 , 18, 28 and 22 for the TAD-MO, TMR-MO, TAD$\mathrm{HO}$ and TMR-MO treatments, respectively (Figure $4 d)$. There were effects $(P<0.05)$ of the $\mathrm{O}$ and Day ${ }^{*} \mathrm{O}$ interaction (Table 2 ) on the milk contents of trans-10, cis-12 CLA. As a function of day, the quadratic regressions were adjusted (Figure 6e). HO SO- and MO SOfed cows showed similar $(P>0.05)$ contents of trans-10, cis-12 CLA on day 1 , but from day 2 , the levels were always higher $(\mathrm{P}<0.05)$ in $\mathrm{MO}$ SO-fed cows (Figure 6e). The maximum milk fat trans-10, cis-12 CLA contents estimated for MO SO- (day 15) and HO SO-fed cows

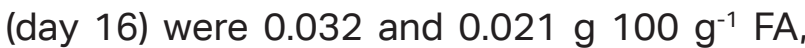
respectively.

There were effects $(P<0.05)$ of $M$ and the Day* $M$ interaction for the milk fat OBCFA content (Table 2), and the quadratic regressions $(P<0.05)$ as a function of day were adjusted for TMR- and TAD-fed cows, with the estimated minimum levels of 2.579 and

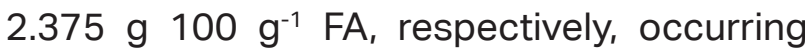
close to the $16^{\text {th }}$ day. Every day, TMR-fed cows presented higher $(P<0.05)$ levels than TAD-fed cows (Figure $5 \mathrm{~d}$ ).

There was an effect $(P=0.0214)$ of $M$ on SCD activity for the oleic/stearic acid pair; TAD-fed cows showed higher $(P<0.05)$ activity than TMR-fed cows (0.4995 versus 0.4895) on days 2, 3, 6 and 15. For the SCD activity of the rumenic/vaccenic acid pair, there was only a day effect $(P<0.0001)$, but no linear or quadratic regressions $(P>0.05)$ were adjusted.

The highly significant day effect for all the variables (Tables 1 and 2) is indicative of the extent of the transformations in the rumen during the 21 days of the study, notably those related to the processes of the $\mathrm{BH}$ of FAs consumed by cows. Rumen $\mathrm{BH}$ is determined by the pool size of available FAs, rumen retention time, and bacterial hydrogenation capacity and is a function of the bacterial population and rumen environment (Harvatine \& Allen, 2004). In addition, BH capacity is timedependent and closely associated with the adaptation of the rumen microbiota to the characteristics of the diet (Rico et al., 2015a).

Daily intake of oleic, linoleic and $\alpha$-linolenic acids was higher in TMR-fed cows only on the first day, probably in response to the higher DM intake also observed on this day for these cows. On the third day, despite still being significant $(P<0.05)$, the difference in the DM intake of TMR- versus TAD-fed cows was smaller and no longer influenced the intake of monounsaturated (MUFA) oleic acid and polyunsaturated (PUFA) linoleic and $\alpha$-linolenic acids (Figures $1 \mathrm{a}, 1 \mathrm{~b}$ and $1 \mathrm{c}$ ). Therefore, if the intake of these unsaturated FAs was equal from day 3 to 21 between the TMR- and TAD-fed cows, then why were there so many differences between them in terms of the apparent transfer of oleic, linoleic and $\alpha$-linolenic acids into milk (Table 1 ), in terms of the plasma contents of vaccenic acid and OBCFA, and in terms of the milk fat content of several FAs, notably, stearic, vaccenic, elaidic and rumenic acid, OBCFA and $\Sigma$ trans-C18:1 FAs (Table 2)? It is likely that the explanation 
for these phenomena lies in the differences in the MUFA and PUFA loads that reached the rumen of cows throughout the day. In TMR-fed cows, the unsaturated FA load that reached the rumen was supposedly better distributed over a 24-hour period and did not exceed the hydrogenating capacity, preventing potential deleterious effects on the resident microbiota. On the other hand, the high MUFA and, mainly, PUFA loads that reached the rumen of TADfed cows at each time point of the concentrate supply may have compromised the resident microbiota's $\mathrm{BH}$ capacity as well as caused an intense dysbiosis on microbial population, possibly impairing the development of species and communities of bacteria more vulnerable to the toxic effects of these unsaturated FAs, notably PUFA. These changes may have slowed the rumen fermentation process and synergistically contributed to the lower DM intake of TAD-fed cows on days 1 and 3 of diet supply (Figure 1a). This hypothesis is supported by the higher OBCFA contents in milk fat (Figure $5 \mathrm{~d}$ ) and plasma in TMR- versus TAD-fed cows. OBCFAs have been used as indirect noninvasive markers of rumen function (Zhang, Liu, Hao, \& Xin, 2017); they originate from the digestion and absorption of lipids synthesized by ruminal bacteria as well as from de novo FA synthesis in the mammary gland (Prado, Schmidely, Nozière, \& Ferlay, 2019). In addition, there were higher plasma vaccenic acid contents (days 9, 15 and 21; Figure 3a) in TAD-fed cows, indicating that there was a need for a more intense $\mathrm{BH}$ process via the classical trans-11 pathway (Shingfield et al., 2010) in the rumen of these cows, aiming to minimize the toxic effects of PUFAs on the rumen bacterial microbiota (Maia et al., 2010). This process can be confirmed, at least in part, by the higher correlations $(P<0.0001, n=60)$ between the plasma vaccenic acid content and linoleic and $\alpha$-linolenic acid intake in TAD-fed cows ( $r=$ 0.81 and 0.66 , respectively) than in TMR-fed cows ( $r=0.70$ and 0.62 , respectively).

The higher milk fat stearic acid contents (days 6 and 15) partially indicate the higher extension and hydrogenating capacity in the rumen of TMR-fed cows as well as reflect the lower $(P<0.05)$ SCD activity of the oleic/stearic acid pair in these cows. Likewise, in TAD-fed cows, the higher milk fat contents of $\Sigma$ trans-C18:1 FAs (Figure 5b), composed mainly of vaccenic acid, elaidic acid and trans-10 C18:1, which are rumenderived FA intermediates of unsaturated C18 FA ruminal $\mathrm{BH}$ reactions (Shingfield et al., 2010), indicate that the high MUFA and PUFA loads that reached the rumen of TADfed cows at each time of concentrate supply triggered the need to intensify the ruminal $\mathrm{BH}$ processes. However, apparently, the maximum hydrogenating capacity in the rumen of TADfed cows was reached given that higher rates of the linear increase of the plasma linoleic acid content were observed in TAD-fed cows (0.31 versus 0.20 for TAD-HO- and TMR-HOfed cows; and 0.57 versus 0.42 for TAD-MOand TMR-MO-fed cows, respectively; Figure 4a), indicating, at least in part, a higher escape of dietary linoleic acid in TAD-fed cows. This hypothesis is supported by the positive correlations $(\mathrm{P}<0.0001)$ between the plasma linoleic acid content and linoleic acid intake in TMR-fed cows ( $r=0.48, n=60)$ and TAD-fed cows $(r=0.62, n=59)$.

In comparison with TMR-fed cows, the milk fat of TAD-fed cows presented a more nutritionally desirable FA profile for human health, such as lower contents of hypercholesterolemic FAs (palmitic acid and ¿C12:0-C16:0; Figure 5a), higher maximum

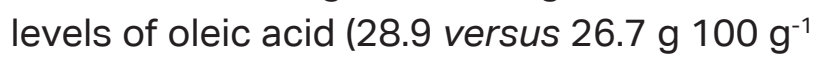


FA for TAD- and TMR-fed cows, respectively) and higher contents of rumenic (Figure $5 \mathrm{c}$ ) and vaccenic acids (Figure 4b). Anticarcinogenic, antidiabetogenic (type 2 diabetes) antiatherogenic and immunomodulatory properties have been attributed to rumenic acid (Yang et al., 2015). Diets that promote an increase in the supply of vaccenic acid from plasma to the mammary gland generally lead to higher milk fat rumenic acid contents; vaccenic acid is the precursor for the synthesis of $64-97 \%$ of rumenic acid in bovine milk (Shingfield et al., 2010). As there was no $M$ effect on SCD activity for the rumenic/ vaccenic FA pair (Table 2), the higher milk fat rumenic acid content in TAD-fed cows (Figure 5c) was mainly due to their higher plasma vaccenic acid content (Figure 3a). This finding is corroborated by the regressions $(P<0.0001)$ between the milk fat rumenic acid content ( $y$; $g$ $100 \mathrm{~g}^{-1} \mathrm{FA}$ ) and plasma vaccenic acid content ( $x ; g 100 \mathrm{~g}^{-1} \mathrm{FA}$ ), where the intercept and linear coefficient were higher for TAD-fed cows $(\hat{y}=$ $\left.0.70897 x+0.97064 ; r^{2}=0.61\right)$ than for TMRfed cows $\left(\hat{y}=0.58907 x+0.83743 ; r^{2}=0.56\right)$. However, even though there was no $M$ effect (Table 1) on the plasma rumenic acid content ( $\mathrm{x} ; \mathrm{g} 100 \mathrm{~g}^{-1} \mathrm{FA}$ ), it contributed to the increase in the milk fat rumenic acid content (y; g 100 $\left.\mathrm{g}^{-1} \mathrm{FA}\right)$, as shown by regressions $(\mathrm{P}<0.01): \hat{y}=$ $3.08546 x+1.08859 ; r^{2}=0.14$ (for TMR fedcows) and $\hat{y}=6.05646 x+1.16171 ; r^{2}=0.17$ (for TAD-fed cows).

Inbothmethods of concentratefeeding a linear increase in DM intake was observed (Figure 1a), with the rate of increase being higher in TAD-fed cows (0.077 versus 0.055$)$, which indicates that the intensification of $\mathrm{BH}$ reactions of unsaturated C18 FAs in the rumen of TAD-fed cows, as discussed earlier, was effective in minimizing the potential deleterious effects of unsaturated FAs, notably PUFAs, on the resident microbiota. This minimization allowed for a gradual return of rumen function, promoting the increases observed in DM intake throughout the 21 days of the study (Figure 1a). This finding is also supported by the linear reductions in the apparent transfer of linoleic and $\alpha$-linolenic acids into milk (Figure 1d), showing an apparent increase in the $\mathrm{BH}$ intensity of these PUFAs. However, it should be noted that in both methods, the effect of SO intake probably promoted drastic changes in the populations of the rumen resident microbiota, which are more intense in TAD-fed cows, for all the reasons discussed earlier. The amazing adaptability of the ruminal microbiota allowed for a slow but gradual achievement of a ruminal $\mathrm{BH}$ status that was compatible with the need imposed by the new scenario of the high unsaturated C18 FA load in the rumen. This finding can be verified by quadratic adjustments as a function of day on the OBCFA contents in milk fat of TMR- and TAD-fed cows (Figure 5d). Reductions in the milk fat OBCFA contents were observed until close to the $16^{\text {th }}$ day, and thereafter, there was an increase, indicating the recovery of ruminal function.

The milk of TMR- and TAD-fed cows produced between days 13 and 17 showed a healthier FA profile, with maximum levels of oleic, vaccenic and rumenic acids, which are beneficial to human health, and minimum levels of hypercholesterolemic lauric, myristic and palmitic acids (Figures 4b, 4c, 5a and 5b).

Consistentwith the dietFAcomposition, HO SO-fed cows presented higher oleic acid intake, while MO SO-fed cows showed higher linoleic and $\alpha$-linolenic acid intake (Figures $2 b$ and $2 c)$. The greater the degree of FA unsaturation, the greater its harmful effect on 
the ruminal microbiota (Maia et al., 2010). Thus, it is likely that the higher intake of PUFAs by $\mathrm{MO}$ SO-fed cows (Figure 2c) more aggressively impaired the development of specific rumen bacteria more vulnerable to their toxic effects and, consequently, slowed the rumen fermentation process and contributed to the lower DM intake of these cows on the first day of supply of the diets (Figure 2a). The reduction of the OBCFA contents in the milk of $\mathrm{HO}$ SO- and MO-SO-fed cows through the study (Figure 6f) corroborates this finding because it is indicative of a decrease in the rumen fermentation process. However, the linear increases of the DM intake and, consequently, of the MUFA and PUFA intakes (Figures $2 a$ and 2c) are indicative of the gradual adaptation of the rumen microbiota of HO SO-fed cows, but mainly in MO SO-fed cows, to the toxic effects of the intake of these unsaturated-C18 FAs. The milk fat OBCFA content was reduced until reaching minimum values on the $15^{\text {th }}$ and $16^{\text {th }}$ days for HO SO- and MO SO-fed cows, respectively. Thereafter, in both oils, there was an increase in the milk fat OBCFA content, indicating the recovery of rumen function, which, however, occurred more slowly in MO SO-fed cows (Figure 6f) that consumed more PUFAs (Figure 2c). The largest apparent transfer of $\alpha$-linolenic acid (day 9) and linoleic acid into the milk of $\mathrm{HO}$ SO-fed cows (Figure $2 \mathrm{~d})$ demonstrates that the $\mathrm{BH}$ of these PUFAs in the rumen of MO SO-fed cows was more intense in response to the higher intake of these FAs (Figure 2c) and, consequently, the urgent need to reduce their toxicity to the ruminal microbiota (Maia et al., 2010).

Due to the less toxic nature of oleic acid to the rumen microbiota (Maia et al., 2010), its $\mathrm{BH}$ was less intense, which allowed its escape from the rumen, verified, at least in part, by the higher content of oleic acid in the plasma of HO SO-fed cows on days 9, 15 and 21 (Figure $3 d)$ as a reflection of the higher intake of oleic acid by these cows (Figure 2b). As there was no effect of $O$ on SCD activity for the oleic/stearic FA pair (Table 2), the higher milk fat oleic acid content in $\mathrm{HO}$ SO-fed cows (notably in TADfed cows; Figure 4c) was mainly due to their higher plasma oleic acid content (Figure 3d). This finding is corroborated by the correlation between the oleic acid content in plasma and milk, which was significant only for $\mathrm{HO}$ SOfed cows ( $r=0.52, P<0.0001, n=58$ ). Milk fat with a higher oleic acid content is desirable for human health, as this FA is associated with beneficial effects on cardiovascular health (Hammad, Pu, \& Jones, 2016).

In addition, the escape of $\alpha$-linolenic, linoleic and oleic acids from the rumen to the next sections of the gastrointestinal tract and, consequently, to plasma (Figures $4 a$ and $3 d$ ) helps to relieve the load of these unsaturated C18 FAs in the rumen, and their $\mathrm{BH}$, transforming these FAs into another less invasive form for the ruminal microbiota, allows a significant reduction in their toxic potential (Maia et al., 2010). Due to the greater bacteriostatic power of the PUFAs, BH was more intense in $\mathrm{MO}$ SO-fed cows, with more evident reflexes in the FA profile of milk fat being perceived, mainly from days 2 and 3 . As a result of the $\mathrm{BH}$ reactions of unsaturated C18 FAs, several well-known rumen-derived FAs were formed, with an emphasis on elaidic, vaccenic and rumenic acids; trans-10 C18:1; trans-9, cis-11 CLA; and trans-10, cis-12 CLA (Shingfield et al., 2010). However, other FAs (data not shown) were also formed, such as trans-4 C18:1, trans-5 C18:1, trans-6-8 C18:1, trans-12 C18:1, trans-13-14 C18:1, trans-16 C18:1, cis-11 C18:1, cis-12 C18:1, cis-13 
C18:1, trans-9, trans-12 C18:2, cis-9, trans-12 C18:2 and trans-9, cis-12 C18:2.

Elaidic acid and trans-10 C18:1 are recurrent intermediates in the oleic and linoleic acid $\mathrm{BH}$ pathways (Shingfield et al., 2010). The positive correlations $(P \leq 0.0001)$ between oleic and linoleic acid intake and the plasma contents of elaidic acid and trans-10 C18:1 in HO SOcows $(r=0.49-0.78, n=56)$ and MO SO-fed cows ( $r=0.53-0.67, n=63$ ) demonstrate that these FAs are, in fact, important intermediates for these $\mathrm{BH}$ reactions. $\mathrm{HO}$ SO-fed cows had higher milk fat elaidic acid contents on day 2 , while MO SO-fed cows had higher trans-10 C18:1 milk fat levels on day 3 (data not shown). It should be noted that the reduction in the milk fat contents of these FAs is desirable for human nutrition since they are associated with deleterious effects on cardiovascular health (Vahmani, Meadus, Duff, Rolland, \& Dugan, 2017).

Vaccenic acid is the main rumenderived FA intermediate of linoleic and $\alpha$-linolenic acids $\mathrm{BH}$ and is also formed in a secondary pathway of oleic acid $\mathrm{BH}$ (Shingfield et al., 2010). Higher contents of this FA were observed in the plasma (Figure 3a) and milk fat (Figure 4b) of MO SO-fed cows, which consumed more PUFAs (Figure 2c). The importance of the plasma vaccenic acid content for its yield in milk is demonstrated by the correlation $(P<0.0001)$ between these variables ( $r=0.68, n=58$ for HO SO-fed cows; and $r=0.65, n=62$ for MO SO-fed cows). In addition, vaccenic acid is the precursor for the synthesis of $64-97 \%$ rumenic acid in bovine milk (Shingfield et al., 2010), and the correlations $(P<0.0001)$ between the plasma vaccenic acid content and the milk fat rumenic acid content ( $r=0.69, n=58$ for HO SO-fed cows; and $r=0.65, n=62$ for MO SO-fed cows) corroborate this. For MO SO-fed cows (but not for HO SO-fed cows), there was a correlation $(P=0.0368)$ between the rumenic acid content in plasma and in milk ( $r=0.27, n=62)$, which indicates that part of the rumenic acid yield in the milk of these cows came from their direct uptake in plasma by the mammary gland. Therefore, as a consequence of the larger plasma vaccenic and rumenic acid contents (Figures $3 \mathrm{a}$ and $3 \mathrm{~b}$ ), MO SO-fed cows showed a higher milk fat rumenic acid content (Figure 5c).

In addition to rumenic acid, two other CLAs (trans-10, cis-12 CLA and trans-9, cis11 CLA) are also intermediates for linoleic acid $\mathrm{BH}$ and, together with trans-10 C18:1, are associated with the reduction of lipogenesis in the cow mammary gland (Bernard et al., 2018; Prado et al., 2019). There was no effect of $O$ on the plasma trans-10, cis-12 CLA and trans-9, cis-11 CLA levels (Table 1). However, due to their higher linoleic acid intake (Figure 2c), MO SO-fed cows showed higher milk fat contents of these CLAs on the $2^{\text {nd }}$ (Figure 6e) and $3^{\text {rd }}$ days (Figure $4 d$ ) as well as trans-10 C18:1. Dietary linoleic acid is more potent than dietary oleic acid in causing MFD $(\mathrm{He}$, Perfield, Green, \& Armentano, 2012), but for both oils, there was no correlation $(P>0.05, n$ $=84$ ) between the milk fat contents of these three FAs and the milk fat content, which was always higher than the $3.0 \%$ established as the standard by the Brazilian legislation for raw milk composition (Instrução Normativa $n^{\circ} 76$, 2018). Thus, it is possible that these FAs were not at sufficient levels to cause MFD.

There was no effect of $O$ on the milk fat contents of de novo-synthesized short chain FAs ( $\Sigma$ C4:0-C10:0). MOSO-fed cows presented higher milk fat contents of $\Sigma \mathrm{C} 12: 0-\mathrm{C} 16: 0$ on days 6 and 15 (Figure 6a). However, there 
were gradual reductions in their milk contents of $\Sigma \mathrm{C} 4: 0-\mathrm{C} 10: 0$ and $\Sigma \mathrm{C} 12: 0-\mathrm{C} 16: 0$, with minimum levels observed between days 15 and 16 for $\Sigma \mathrm{C} 4: 0-\mathrm{C} 10: 0$ (data not shown) and close to day 13 for $\Sigma \mathrm{C} 12: 0-\mathrm{C} 16: 0$ (Figure 6a). The high negative correlations $(P<0.0001, n=$ 94) between the milk fat contents of trans-10 C18:1, trans-10, cis-12 CLA and trans-9, cis-11 CLA and the milk fat contents of $\Sigma C 4: 0-C 10: 0$ $(r=-0.53$ to -0.81$)$ and $\Sigma C 12: 0-C 16: 0(r=-0.51$ to -0.78 ) can be considered indicative that these FAs inhibited, at least in part, lipogenesis in the mammary gland via the reduction of de novo FA synthesis (Bernard et al., 2018; Prado et al., 2019). Another hypothesis to explain the reduction in milk fat contents of de novosynthesized FAs concerns the competition of C18 FA with de novo-synthesized FAs for esterification into triglycerides of milk fat (Prado et al., 2019). This is supported by the negative correlations $(P<0.0001, n=94)$ between the milk contents of $\Sigma \mathrm{C} 4: 0-\mathrm{C} 10: 0(\mathrm{r}$ $=-0.63$ to -0.87$)$ and $\Sigma \mathrm{C} 12: 0-\mathrm{C} 16: 0(r=-0.65$ to -0.88 ) and those of several unsaturated $\mathrm{C} 18$ FAs (e.g., elaidic, vaccenic, oleic and rumenic acids).

At least in part, the linear increase in the plasma linoleic acid content (Figure 4a) may have been promoted by its greater escape from the rumen in response to the linear increase in its intake (Figure 2c). In contrast, a linear reduction was observed in its milk fat content (Figure 6c). Linoleic and $\alpha$-linolenic acids are essential FAs, and their low transfer into milk could be the result of changes in the FA composition of the different lipid fractions present in blood plasma (Jacobs et al., 2011), reflecting different patterns of plasma availability of these FAs for mammary uptake (Prado et al., 2019). To partially illustrate these different patterns, in MO SO-fed cows, the correlation of linoleic acid intake was positive with the linoleic acid plasma content ( $r=0.55, n=63, P<0.0001$ ) but negative with the milk fat linoleic acid content $(r=-0.30, n$ $=94, P=0.0030$ ). A higher linoleic acid content in milk fat was observed in MO SO-fed cows from day 3 onwards (Figure 6c). Despite the increase in $\alpha$-linolenic acid intake (Figure 2c), there was no effect on its plasma content (Table 1). The milk fat $\alpha$-linolenic acid content was higher in MO SO-fed cows on days 2 and 3 and was similar to that in $\mathrm{HO}$ SO-fed cows on the other days (Figure $6 \mathrm{~d}$ ). From day 3 , there was an increase in the $\alpha$-linolenic acid $\mathrm{BH}$ due, at least in part, to the better adaptation of the ruminal microbiota to the load of unsaturated C18 FAs.

In comparison with $\mathrm{MO}$ SO-fed cows, the milk fat of $\mathrm{HO}$ SO-fed cows presented lower contents of hypercholesterolemic acids (lauric, palmitic acid and $\Sigma$ C12:0-C16:0) and higher milk fat contents of oleic acid, especially in TAD-fed cows (Figures 6a and 4c). On the other hand, MO SO-fed cows presented lower contents of myristic acid and higher milk fat contents of vaccenic (Figure $4 b$ ) and rumenic acids (Figure $5 \mathrm{c}$ ). Considering the days when the maximum or minimum levels of specific FAs were estimated to occur, in $\mathrm{MO}$ SO-fed cows, the milk fat contents of vaccenic and rumenic acids were $81 \%$ higher and the myristic milk fat content was $7 \%$ lower than in $\mathrm{HO} S \mathrm{~S}-$ fed cows. On the other hand, in $\mathrm{HO}$ SO-fed cows, the oleic acid milk fat content was $14 \%$ higher and the milk fat contents of lauric and palmitic were $7 \%$ lower than those in MO SO-fed cows. The milk of MO SO-fed cows produced between days 13 and 16 showed a healthier FA profile with maximum contents of oleic, vaccenic and rumenic acids and minimum contents of lauric, myristic and 
palmitic acids. For HO SO-fed cows, only after 19 days did the maximum milk fat content of rumenic acid occur, and therefore, a healthier milk FA profile was obtained between days 13 and 19.

\section{Conclusions}

Twenty-one days was sufficient to understand the main changes in plasma and milk fatty acid profiles for cows fed chopped elephant grass-based diets with $45 \mathrm{~g} \mathrm{~kg}^{-1}$ DM high or medium oleic acid sunflower oil supplied in a concentrate separately from forage twice a day or as part of a TMR.

In comparison with TMR-fed cows, the milk of cows fed with concentrate supplied twice a day, obtained between days 13 and 17 showed a healthier fatty acid profile, such as lower contents of hypercholesterolemic fatty acids and higher contents of oleic, rumenic and vaccenic acids.

Between days 15 and 16, the contents of vaccenic and rumenic acids in the milk fat of cows fed with medium oleic sunflower oil were $81 \%$ higher than those obtained from cows that received high oleic sunflower oil, which, on the $14^{\text {th }}$ day, had a $14 \%$ higher oleic acid content in milk fat. A lower milk fat content of hypercholesterolemic FAs was obtained between days 13 and 14 for cows fed both types of sunflower oil.

\section{Acknowledgments}

The authors gratefully acknowledge the Fundação de Amparo à Pesquisa de Minas Gerais (Fapemig), Conselho Nacional de Desenvolvimento Científico e Tecnológico (CNPq) and Embrapa Dairy Cattle for scholarships and for financial support of this study.Wewouldalsoliketothankthetechnicians Ernando Ferreira Motta and Hernani Guilherme Barbosa Filho, who performed the analyses of fatty acid composition at the Laboratory of Chromatography of Embrapa Dairy Cattle.

\section{References}

Bernard, L., Bonnet, M., Delavaud, C., Delosière, M., Ferlay, A., Fougère, H., \& Graulet, B. (2018). Milk fat globule in ruminant: major and minor compounds, nutritional regulation and differences among species. European Journal of Lipid Science and Technology, 120(5), 1700039. doi: 10.10 02/ejlt.201700039

Fuentes, M. C., Calsamiglia, S., Cardozo, P. W., \& Vlaeminck, B. (2009). Effect of pH and level of concentrate in the diet on the production of biohydrogenation intermediates in a dual-flow continuous culture. Journal of Dairy Science, 92(9), 4456-4466. doi: 10.3168/jds.2008-1722

Hammad, S., Pu, S., \& Jones, P. J. (2016). Current evidence supporting the link between dietary fatty acids and cardiovascular disease. Lipids, 51(5), 507-517. doi: 10.10 07/s11745-015-4113-x

Harvatine, K. J., \& Allen, M. S. (2004). Kinetic model of rumen biohydrogenation: fractional rates of fatty acid biohydrogenation and passage. Journal of Animal and Feed Sciences, 13(Suppl. 1), 87-90. doi: 10.22358/jafs/73745/2004

He, M., Perfield, K. L., Green, H. B., \& Armentano, L. E. (2012). Effect of dietary fat blend enriched in oleic or linoleic acid and monensin supplementation on dairy cattle 
performance, milk fatty acid profiles, and milk fat depression. Journal of Dairy Science, 95(3), 1447-1461. doi: 10.3168/ jds.2011-4635

Instrução Normativa $\mathrm{n}^{\circ} 76$, de 26 de novembro de 2018. Diário Oficial da União $n^{\circ} 230$ - Seção 1. Ministério da Agricultura, Pecuária e Abastecimento.

Jacobs, A. A. A., van Baal, J., Smits, M. A., Taweel, H. Z. H., Hendriks, W. H., van Vuuren, A. M., \& Dijkstra, J. (2011). Effects of feeding rapeseed oil, soybean oil, or linseed oil on stearoyl-CoA desaturase expression in the mammary gland of dairy cows. Journal of Dairy Science, 94(2), 874-887. doi: 10.3168/jds.2010-3511

Kelsey, J. A., Corl, B. A., Collier, R. J., \& Bauman, D. E. (2003). The effect of breed, parity, and stage of lactation on conjugated linoleic acid (CLA) in milk fat from dairy cows. Journal of Dairy Science, 86(8), 2588-2597. doi: 10.3168/jds.S0022-0302 (03)73854-5

Lopes, F. C. F., Ribeiro, C. G. S., Rodriguez, N. M., Gama, M. A. S., Morenz, M. J. F., Antoniassi, R., \& Bizzo, H. R. (2019). Butter fatty acid composition as a function of soybean oil supplementation and time of milking, and performance of Holstein x Gyr cows fed with chopped elephant grass-based diets. Semina: Ciências Agrárias, 40(5), 20272044. doi: 10.5433/1679-0359.2019v40n 5 p2027

Lopes, F. C. F., Ribeiro, C. G. S., Rodriguez, N. M., Gama, M. A. S., \& Morenz, M. J. F. (2020). Milk fatty acid composition in Holstein $x$ Gyr dairy cows fed chopped elephant grass-based diets containing two types of sunflower oil associated with two methods of concentrate feeding. Semina: Ciências Agrárias, 41(6), 2761-2780. doi: 10.5433/1679-0359.2020v41n6p2761

Maia, M. R. G., Chaudhary, L. C., Bestwick, C. S., Richardson, A. J., McKain, N., Larson, T. R.,... Wallace, R. J. (2010). Toxicity of unsaturated fattyacids to the biohydrogenating ruminal bacterium, Butyrivibrio fibrisolvens. BMC Microbiology, 10(52), 1-10. doi: 10.1186/ 1471-2180-10-52

Masood, A., Stark, K. D., \& Salem, N, Jr. (2005). A simplified and efficient method for the analysis of fatty acid methyl esters suitable for large clinical studies. Journal of Lipid Research, 46(10), 2299-2305, 2005. doi: 10.1194/jlr.D500022-JLR200

Mourthé, M. H. F., Lopes, F. C. F., Reis, R. B., Gama, M. A. S., Morenz, M. J. F., \& Salomão, B. M. (2019). Ruminal metabolic parameters and milk fatty acid profile of cows grazing Marandu grass supplemented with roasted soybeans. Semina: Ciências Agrárias, 40(2), 745-766. doi: 10.5433/1679-0359. 2019v40n2 p745

National Research Council (2001). Nutrients requirements of dairy cattle (7nd ed.). Washington: National Academy Press.

Prado, L. A., Schmidely, P., Nozière, P., \& Ferlay, A. (2019). Milk saturated fatty acids, oddand branched-chain fatty acids, and isomers of C18:1, C18:2, and C18:3n-3 according to their duodenal flows in dairy cows: A meta-analysis approach. Journal of Dairy Science, 102(4), 3053-3070. doi: 10.3168/jds.2018-15194

Ribeiro, C. G. S., Lopes, F. C. F., Rodriguez, N. M., Gama, M. A. S., \& Morenz, M. J. F. (2018). Ruminal fermentation and degradation, kinetic flow of the digesta 
and milk fatty acid composition of cows fed chopped elephant grass supplemented with soybean oil. Semina: Ciências Agrárias, 39(4), 1775-1794. doi: 10.5433/1679-0359.2018v39n4p1775

Rico, D. E., Holloway, A. W., \& Harvatine, K. J. (2015a). Effect of diet fermentability and unsaturated fatty acid concentration on recovery from diet-induced milk fat depression. Journal of Dairy Science, 98(11), 7930-7943. doi: 10.3168/jds.20148990

Rico, D. E., Preston, S. H., Risser, J. M., \& Harvatine, K. J. (2015b). Rapid changes in key ruminal microbial populations during the induction of and recovery from dietinduced milk fat depression in dairy cows. British Journal of Nutrition, 114(3), 358367. doi: $10.1017 / S 0007114515001865$

Shingfield, K. J., Bernard, L., Leroux, C., \& Chilliard, Y. (2010). Role of trans fatty acids in the nutritional regulation of mammary lipogenesis in ruminants. Animal, 4(7), 1140-1166. doi: 10.1017/S17517311100 00510
Vahmani, P., Meadus, W. J., Duff, P., Rolland, D. C., \& Dugan, M. E. R. (2017). Comparing the lipogenic and cholesterol genic effects of individual trans-18:1 isomers in liver cells. European Journal of Lipid Science and Technology, 119(3), 1600162. doi: 10. 1002/ejlt.201600162

Yang, B., Chen, H., Stanton, C., Ross, R. P., Zhang, H., Chen, Y. Q., \& Chen, W. (2015, May). Review of the roles of conjugated linoleic acid in health and disease. Journal of Functional Foods, 15, 314-325. doi: 10. 1016/j.jff.2015.03.050

Zhang, Y., Liu, K., Hao, X., \& Xin, H. (2017). The relationships between odd- and branched-chain fatty acids to ruminal fermentation parameters and bacterial populations with different dietary ratios of forage and concentrate. Journal of Animal Physiology and Animal Nutrition, 101(6), 1103-1114. doi: 10.1111/.jpn.12602 
